RICHARD VALLANCE JANKE

The Association of Historical Studies

KORYVANTES

Athens, Greece

vallance22@zoho.com
930.2:003.071(38)

003.326 .1

$811.14^{\prime} 01^{\prime} 255$

COBISS.SR-ID 219293452

Original research article

Received: August 24th 2015

Accepted: November 15th 2015

\title{
AN ARCHAEOLOGIST'S TRANSLATION OF PYLOS TABLET TA 641-1952 (VENTRIS), WITH AN INTRODUCTION TO SUPERSYLLABOGRAMS IN THE VESSELS \& POTTERY SECTOR IN MYCENAEAN LINEAR B
}

\begin{abstract}
In partnership with The Association of Historical Studies, Koryvantes (Athens), our organization, Linear B, Knossos \& Mycenae (Wordpress), conducts ongoing research into Mycenaean archaeology and military affairs and the Mycenaean Greek dialect. This study centres on a fresh new decipherment of Pylos tablet TA 641-1952 (Ventris) by Mrs. Rita Roberts from Crete, who brings to bear the unique perspectives of an archaeologist on her translation, in all probability the most accurate realized to date. We then introduce the newly minted term in Mycenaean Linear B, the supersyllabogram, being the first syllabogram or first syllable of any word or entire phrase in Linear B. Supersyllabograms have been erroneously referred to as "adjuncts" in previous linguistic research into Mycenaean Linear B. This article demonstrates that their functionality significantly exceeds such limitations, and that the supersyllabogram must be fully accounted for as a unique and discrete phenomenon without which any approach to the interpretation of the Linear B syllabary is at best incomplete, and at worse, severely handicapped.
\end{abstract}

KEYWORDS: MYCENAEAN LINEAR B, SYLLABOGRAMS, LOGOGRAMS, IDEOGRAMS, SUPERSYLLABOGRAMS, ADJUNCTS, LINEAR B TABLETS, PYLOS, PYLOS TA 641-1952 (VENTRIS), DECIPHERMENT, TRANSLATION, POTTERY, VESSELS, TRIPODS, CAULDRONS, AMPHORAE, KYLIXES, CUPS, GOBLETS.

Why are there so many ideograms in Mycenaean Linear B, 123 all told, with 30 in the pottery and vessels sector alone? This is no idle question. Of the 123 Linear B ideograms listed in Wikimedia Commons, ${ }^{1}$ fully 30 or $24.5 \%$ are situated in the pottery and vessels sector of the Mycenaean economy, as illustrated in Table 1.

But why so many? As I emphatically pointed out in the talk I gave at The Third Interdisciplinary

1 Wikimedia Commons: Category: Linear B https:// commons.wikimedia.org/wiki/Category:Linear_B?uselang=en-gb
Conference, "Thinking Symbols", June 30-July 1 2015, at the Pultusk Academy of the Humanities, just outside of Warsaw, Poland, in partnership with The Association of Historical Studies, Koryvantes (Athens), with whom our organization, Linear B, Knossos \& Mycenae (Wordpress), is in full partnership, "No-one deliberately resorts to any linguistic device when writing in any language, unless it serves a useful purpose beneficial to more effective communication, contextual or otherwise." (italics mine). Although in that con- 


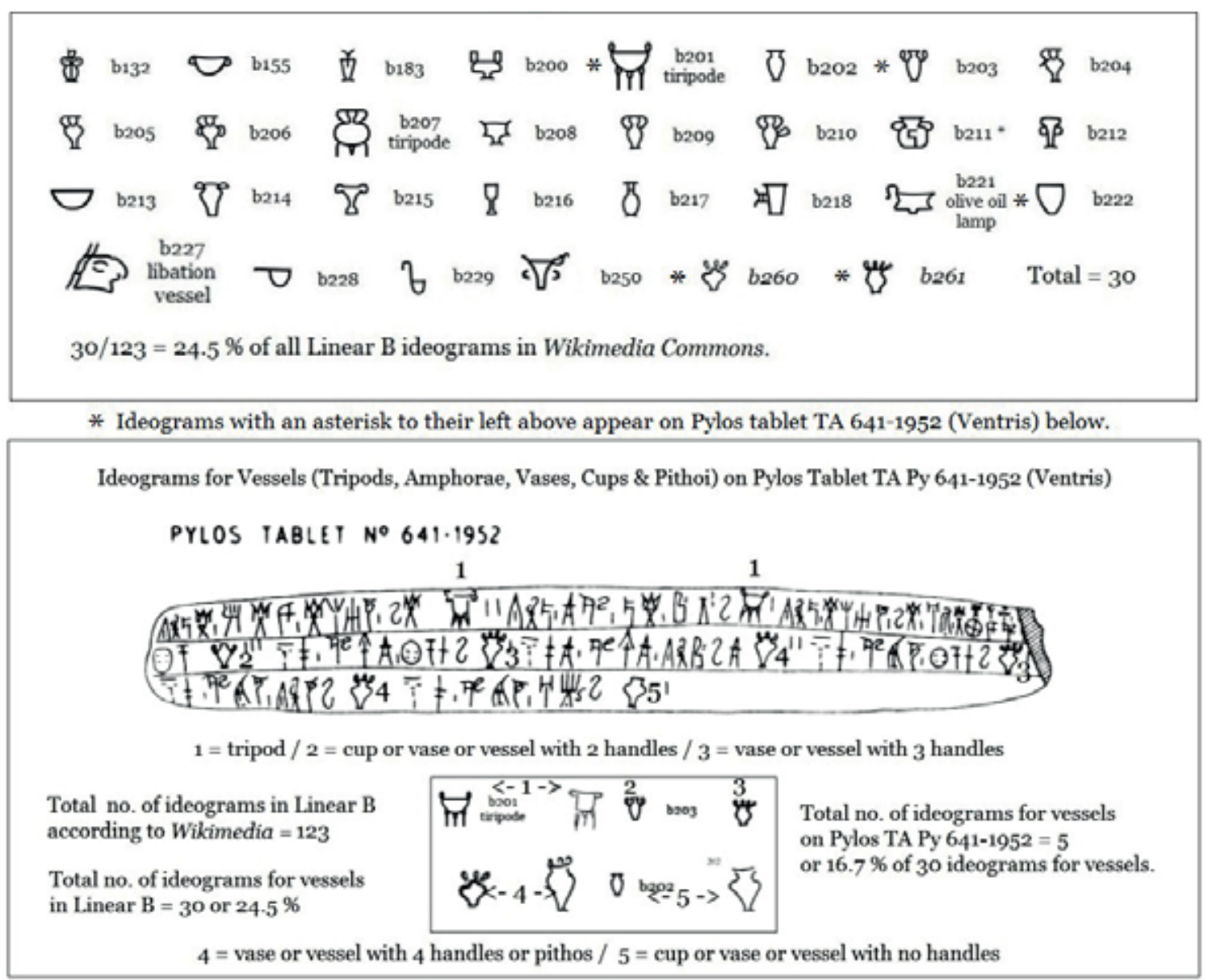

Table 1 Ideograms for vessels in general in Linear B and in particular on Pylos tablet TA 641-1952 (Ventris)

text I was referring to a phenomenon even more striking than the pervasive use of ideograms on Mycenaean Linear B tablets, notably, the device I have newly coined, which I refer to as supersyllabograms, this still remains precisely the point (italics mine). We shall be discussing the phenomenon of supersyllabograms in the last section of this article.

To illustrate in concrete terms what my meaning is, all we need do is take our cue from one of the most famous extant tablets in Mycenaean Linear B. I refer of course to Pylos tablet TA 6411952 (Ventris), the very first tablet Michael Ventris ever translated from $A$ to $Z$. To this day his decipherment stands as one of the high points in the translation of Mycenaean Linear B. While several cogent translations have followed, none have improved all that much on his highly competent decipherment, although all have contributed some new insight into particular aspects, certain words and specific phrases, and in addition, into some or all of the ideograms for vessels which appear on this tablet.

Some historical background is in order. Michael Ventris was not actually the first person to translate the first word on this tablet. It was his friend and professional colleague, the archaeologist Prof. Carl Blegen ${ }^{2}$, who was in the process of unearthing a rich trove of tablets in Mycenaean Linear B at Pylos. He just so happened to stumble upon something truly intriguing about this particular tablet. Even at first glance, he could see that the very first ideogram on the first line was clearly one of a tripod. That was his first clue. With

2 Wikipedia: Carl Blegen https://en.wikipedia.org/wiki/ Carl_Blegen 


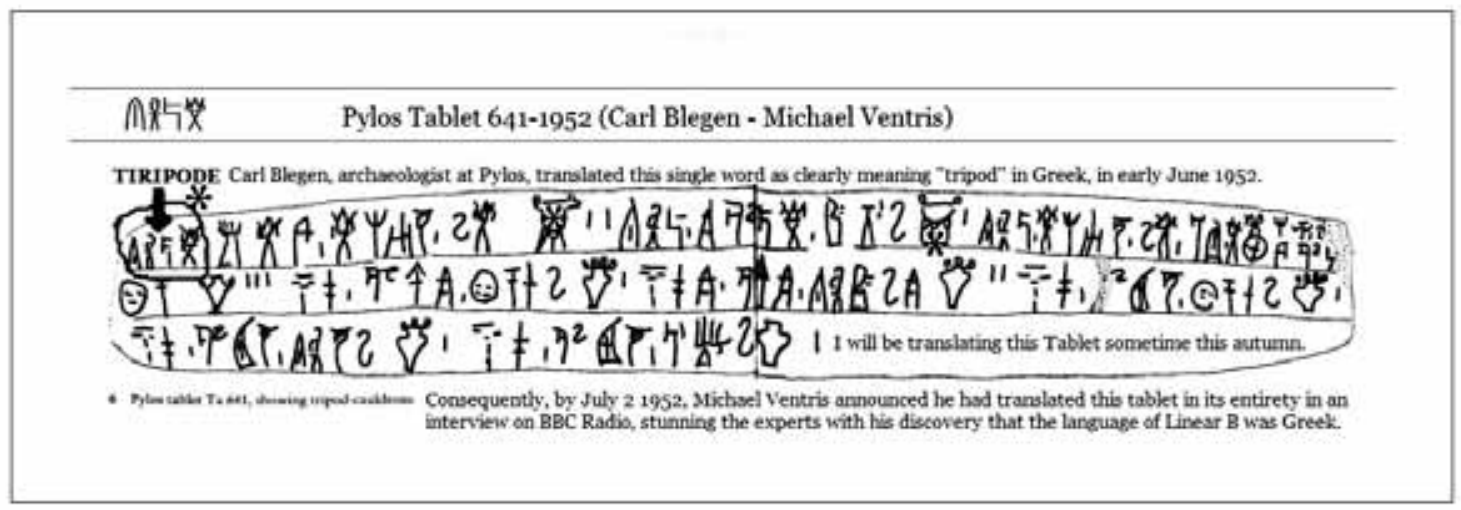

Table 2 Carl Blegen's decipherment of the first word "tiripode", meaning "tripod" on Pylos tablet TA 641-1952 (Ventris)

Michael Ventris' final grid in hand, he was able right off the bat to translate the first word only of the initial phrase on the tablet, on the hunch that, to accord with the ideogram, it just might be the Mycenaean for "tripod". And to his utter astonishment, it spelled out just that, appearing here in Latinized Linear B as "tiripode" in Table 2.

Blegen was beside himself with excitement. He wasted no time communicating his astonishing discovery to Michael Ventris, who in June 1952 immediately fired off a letter to Prof. Emmett L. Bennett Jr. ${ }^{3}$, the American philologist who had already made significant contributions to the search for a convincing decipherment of Linear B through his

3 Wikipedia: Emmett L. Bennett Jr. https://en.wikipedia.org/wiki/Emmett_L._Bennett,_Jr. systematic cataloguing of its characters (apparently syllabograms, given the small number of them, somewhat more than twice as many as in an alphabet) and of its scores of symbols - mark my word clearly ideograms, both of which this script had in common with its immediate predecessor, the as yet undeciphered script, Minoan Linear A. The mere fact that Minoan Linear A and Linear B both contained a substantial number of ideograms, a great many of which they held in common, was enough to convince Carl Blegen that any decipherment of the word which corresponded to the ideogram for "tripod" would simply have to clinch the matter. And he was right on the money. This wonderful news in hand, with uncharacteristic enthusiasm Ventris reported (Fig. 1)

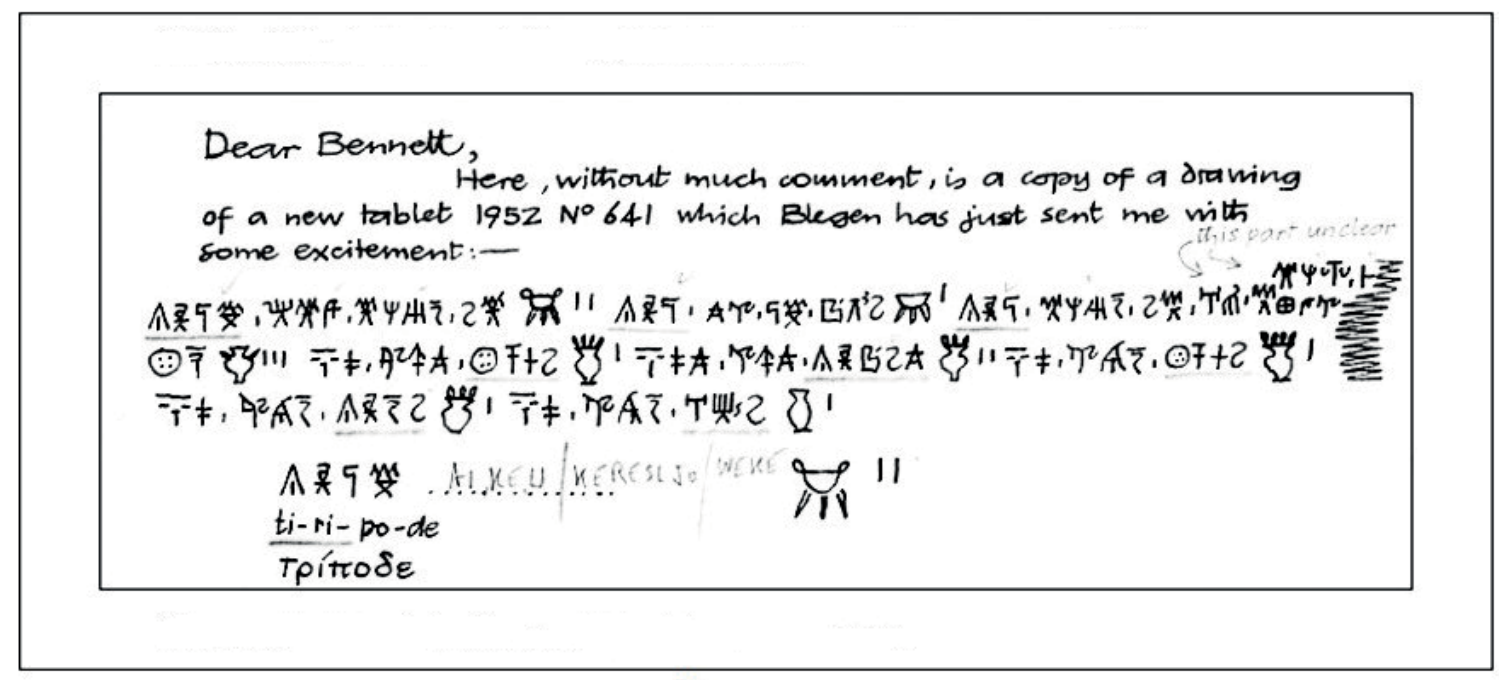

Fig. 1 Michael Ventris' letter to Emmett L. Bennett, 1952 in which he expands on Carl Blegen's decipherment of the first word on Pylos tablet TA 641-1952 (Ventris) 


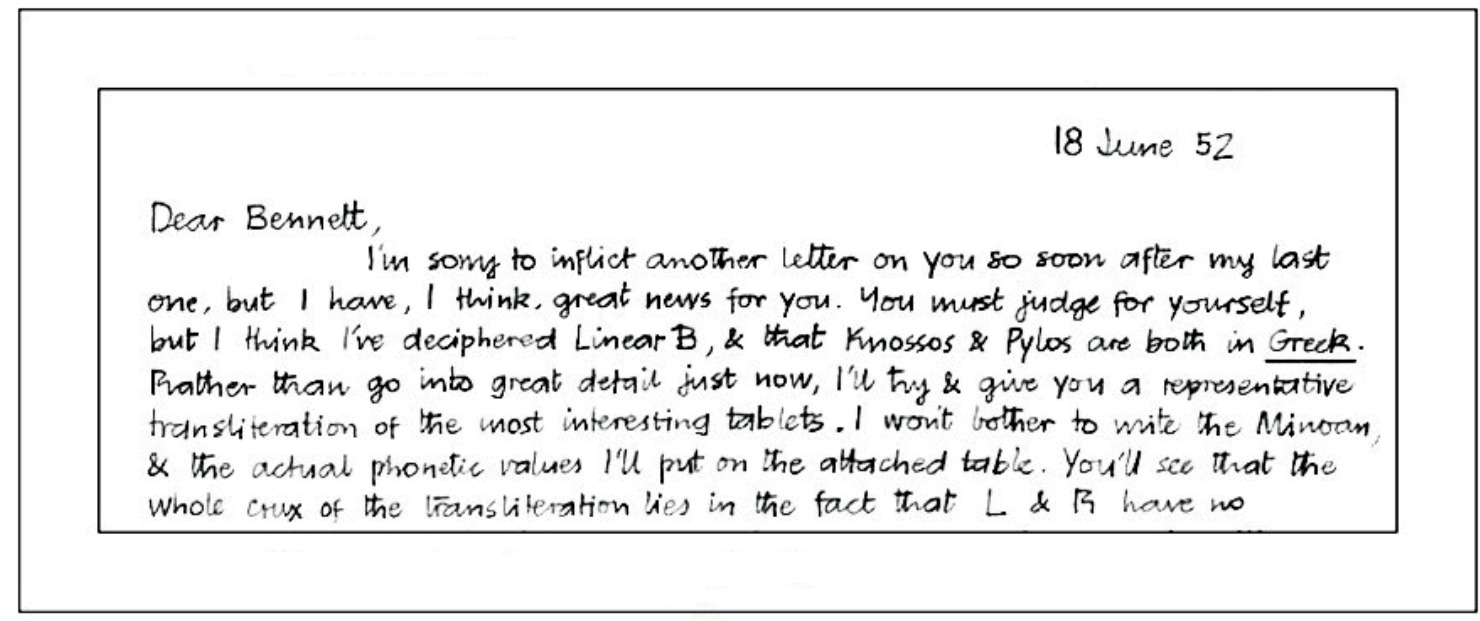

Fig. 2 Michael Ventris' letter to Emmett L. Bennett, June 18 1952, in which he claims he has finally deciphered the Mycenaean Linear B text on Pylos tablet TA 641-1952 (Ventris)

This was almost immediately followed by another letter, which effectively opened the flood gates, allowing for the impending decipherment of the entire tablet (Fig. 2).

The script had effectively been broken. To the equal astonishment of Michael Ventris himself and everyone else in the world then struggling to decipher Linear B, this was nothing less than earth-shattering news. No wonder. Ventris had been struggling for almost five years on the assumption that the language of Linear B was not Greek. For the previous fifty-two years since the first discovery of the ruins of Knossos by Sir Arthur Evans in March 1900, no one in the entire world could have imagined or seriously believed that a script so ancient, especially a syllabary, could conceivably represent either proto-Greek or potentially even the earliest ancient Greek dialect. However, even in the earliest days, immediately after the astonishing archaeological find of Knossos, perhaps the greatest archaeologist of the early twentieth century, Sir Arthur Evans himself, suspected that the syllabary could in fact at least be in proto-Greek, postulating in Scripta Minoa ${ }^{4}$ that, in light of this passage from The Odyssey (Fig. 3),

Translation mine: There is a certain fair and fruitful land, Crete, in the middle of the wine-coloured sea, surrounded by it on all sides. It has an extensive population, and there are nine cities in it. The people speak a number of overlapping

\section{Evans, Arthur J. 1952}

Scripta minoa: the written documents of minoan Crete with special reference to the archives of Knossos (Band 2):

The archives of Knossos: clay tablets inscribed in linear script B - Oxford: Cambridge University Press

http://digi.ub.uni-heidelberg.de/diglit/evans1952/0001/ thumbs?sid=14339521 ba1308ae2d5326fa9d88f789\#/current_page

See pp. 66-68 http://digi.ub.uni-heidelberg.de/diglit/evan s1952/0074?sid=14339521ba1308ae2d5326fa9d88f789

Discussion of the early language or languages of Crete must begin from the Homeric description (Odyssey XIX. 173-7):

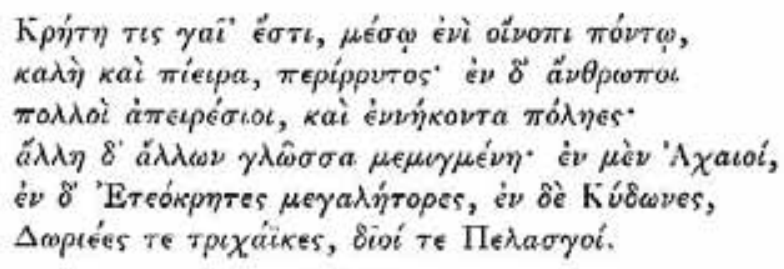

Fig. 3 Homer's description of the early languages of Crete (Odyssey XIX. 173-177) 


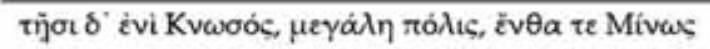

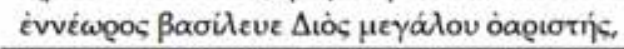

Fig. 4 The reign of god-like Minos, King of Crete, at Knossos (Odyssey XIX. 178-179)

languages. Among them are the Achaeans, the heroic Eteocretans, the fine Kudonians, the Dorians and their three tribes, and the Pelasgians of divine origin.

However, Evans fails to call attention to the next two lines, which are even more significant, and which run as follows (Fig. 4).

Translation mine: In their midst was Knossos, a great city, where Minos, king regnant, was on familiar terms with Zeus,...

With this (apparently mythological) information in hand, Evans goes on to assert: It seems certain, therefore, that Greek speech - and probably two or more dialects of Greek
- were introduced ready-made into Crete; that the latest arrivals, the Doric dialects, did not arrive much before the eleventh century..." (BCE) ${\text { (italics mine })^{5}}$

only to dismiss the notion as ludicrous,

It would seem, therefore, unlikely that the language of the Cretan scripts was any kind of Greek, and probable that it was related to the early language or languages of Western Anatolia - associated, that is, with the archaeological 'cultures' of Alaja Hüyük I ('proto-hattic') and of Hissarlik II and Yortan ('Luvian')...”, and a little further,

5 pg. 67 http://digi.ub.uni-heidelberg.de/diglit/evans1952/ 0075? sid=14339521ba1308ae2d5326fa9d88f789

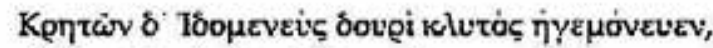

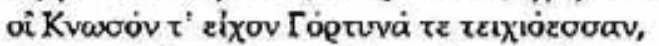

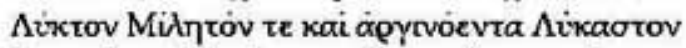

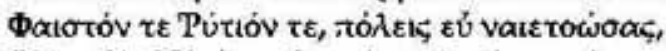

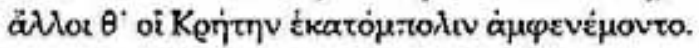

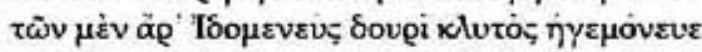

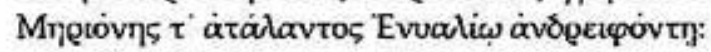

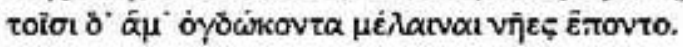
650

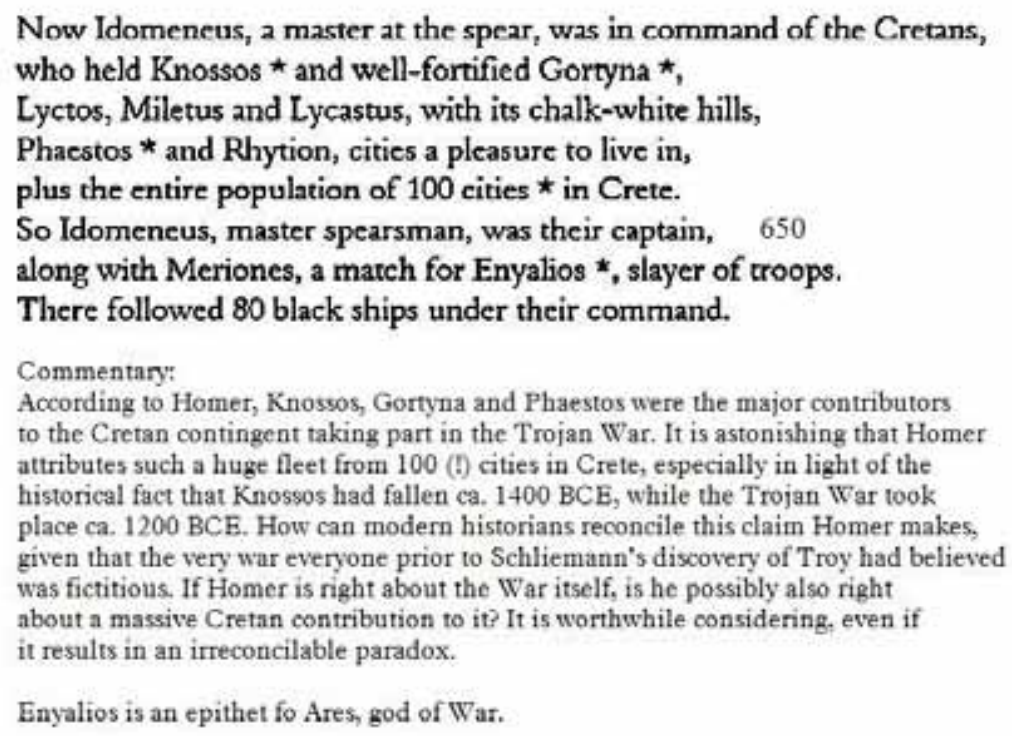

Fig. 5 The critical role Knossos and the 100 cities in Crete played in the Trojan War, according to Homer, in the Catalogue of Ships (lines 645-652), Book II of the Iliad 
"Though many of the sign-groups are compounded from distinct elements, usually of two syllables each, there is little trace of an organized system of grammatical suffixes, as in Greek. At most, a few signs are notably frequent as terminals... (italics mine $)^{6}$ and this in spite of its great antiquity, given that it preceded the earliest known written Greek, The Iliad and The Odyssey of Homer by at least 600 years! It was a perfectly reasonable and plausible assumption, in view of the then understandable utter lack of evidence to the contrary. Besides, there were no extant tablets in either Minoan Linear A or Linear B with parallel text in another known ancient language, as had conveniently been the case with the Rosetta Stone ${ }^{7}$, which would have gone a long way to aiming for a convincing decipherment of at least the latter script.

Yet Evans was nagged by doubts lurking just below the surface of his propositions. Though a brilliant archaeologist of the first order for his day and age - the dawn of modern archaeological methodologies and practices, with its the pervasive lack of any archaeological evidence, supportive or otherwise, of any views he might advance - he has contradicted himself more than once in spite of his clear capacity for remarkable linguistic insights. The contradictions in this passage alone are:

1. Based on the clues to the extreme antiquity of a proto-Greek society and language from the passage in The Odyssey cited above, Evans was tempted to take it at its face value. After all, he must have reasoned, Homer, in both The Iliad and The Odyssey, was closer than anyone in ancient Greece could get to the actual historical time frame in which the Linear B script held sway (ca. 1450-1200 BCE). Although he did not reference yet another strikingly similar passage from The Catalogue of Ships in Book II of The Iliad, Evans

6 pg. 68 http://digi.ub.uni-heidelberg.de/diglit/evans1952/ 0076? sid=14339521 ba1308ae2d5326fadd88f789

7 Wikipedia: Rosetta Stone https://en.wikipedia.org/wiki/ Rosetta_Stone must have surely been aware of it. In the original and in my own translation, it reads as follows (Fig. 5).

If he did indeed take these two passages into account, one from The Iliad and the other from The Odyssey, Evans must have been hard-pressed not to believe the language of Linear B was some sort of (proto-) Greek.

2. He then goes on to affirm that the Dorian dialect was one of the very last arrivals in Crete, apparently implying that there was at least one (proto-) Greek dialect in situ prior to it, i.e. before the eleventh century BCE.

3. Then, strangely, in a bizarre twist of logic, he suddenly asserts that both Linear A and Linear B share the same language. That is a bit of a stretch at best. Yet, even in this assumption, Evans offers a brilliant insight into one possible origin of Minoan Linear A, Luvian, a language which even to this day some researchers still consider to be its cognate. But you cannot have it both ways. Based on the assumption that the values traditionally assigned to each of the syllabograms in Minoan Linear A \& Linear B are either identical or nearly equivalent, and given that words in the same context in these two syllabaries, Linear A and Linear B, even if both entirely undeciphered at that time (the early twentieth century) were completely different, it stood to reason that the language of Linear B could not have been that of Linear A, a perfectly plausible hypothesis which everyone at the time, including Evans himself, entirely overlooked. This is all the more mysterious, given that Evans did posit the entirely reasonable hypothesis that Linear A at least might have been a Luvian derivative. The significance of the clear distinction that should have been made even then between the language underlying Linear $A$ and that of Linear B is of crucial import to our present study.

4. Last but far from least, Evans draws the implausible conclusion that the language of Linear B shows little evidence of an organized system of grammatical suffixes, such as occur in Greek, only 
to flatly contradict himself yet again, asserting,

At most, a few signs are notably frequent as terminals; they seem to replace each other in the same grammatical position and are, therefore, suffixes adhering to the stem, like the substantival - especially agent - endings of the nominative in endings of the nominative in Greek - пр, - $\omega \rho,-i \sigma \tau \eta s,-i \omega \nu, \quad \alpha \nu \delta$ personal endings like -k入̄̄s ; ...” (Scripta Minoa, 68) (italics mine).

However, he is viewing the overall picture with his glass half empty rather than half full. I on the contrary interpret this particular finding as follows: even though there are only a few signs with terminals, given that these are frequent - and Evans makes a point of this - and are in all probability also suffixes and even agents, this is highly significant in and of itself. He has posited these terminals as plausible not only in context and precise word order, but also in their rôle as suffixes in an inflectional language (italics mine). He has covered a lot of bases in such a brief statement. This is why I see his glass as half full. In this regard, the relevance of my cursive analysis of Evans' insights to our understanding of the apparent, even if partial, functionality of Mycenaean Greek grammar in the context of complementary ideograms is of great significance to the furtherance of our understanding of the actual meaning(s) of single words and even entire phrases on extant Linear B tablets, as you are about to witness in our analysis of two translations of Pylos tablet TA 641-1952 (Ventris) below.

5 . He goes on to make another assertion highly relevant to our discussion of the Linear B syllabary, with its frequent reliance on ideograms to replace what would otherwise have been discursive text, for which there was precious little space on what are ostensibly very small clay tablets, the vast majority no wider than $15 \mathrm{~cm}$., with the largest rarely exceeding $30 \mathrm{~cm}$. wide by $60 \mathrm{~cm}$. deep. He then abruptly cuts himself short by asserting, "The rarity, however, of continuous texts, even in the copious B series, makes all conclusions about grammatical structure precarious (Scripta Minoa, pp. 49-50)." Once again, in spite of himself, Evans is onto something big, though he can scarcely be blamed for not being consciously aware of the enormous implications of what he has just said here, given that he was after all the pioneer researcher in the field of Minoan-Mycenaean archaeology and linguistics. It would be too much to ask of him to have made more of what he had gleaned from the fragmentary and baffling evidence he had to work with. That he was able to make as much as he did of it is impressive enough.

Given the historical scenario I have just sketched, it certainly must have come as a shock, however pleasant, to Ventris and his esteemed colleagues, Carl Blegen, Emmett L. Bennett, Prof. John Chadwick et al, that the language of Linear B was a (proto-) Greek dialect. But it was. And that single revelation changed the entire time line of ancient Greek history beyond recognition. Such was the immense impact on linguistic research into ancient Greek of the astounding decipherment of Pylos tablet TA 641-1952. Prof. Chadwick himself, in his laudatory biographical study of Michael Ventris, has this to say ${ }^{8}$ :

One afternoon in May 1953 the telephone rang in my flat in Cambridge. Michael Ventris had called me from London in a great state of excitement - he rarely showed signs of emotion, but for him this was a dramatic moment. The cause was a letter he had received from Professor Blegen, the excavator of Pylos. We knew that Blegen had found more tablets in 1952, but no one had yet examined them carefully; they had been cleaned during the winter and only the next spring were they ready for study. Blegen's letter ran:

Since my return to Greece I have spent much of my time working on the tablets from Pylos, getting them properly ready to be photographed. I have tried your experimental syllabary on some of them.

8 Chadwick, John. 1970

The Decipherment of Linear B. Cambridge, U.K.: Cambridge University Press x, 164 pp. (I)SBN 521-09596-4 (pbk.) See pg. 81 


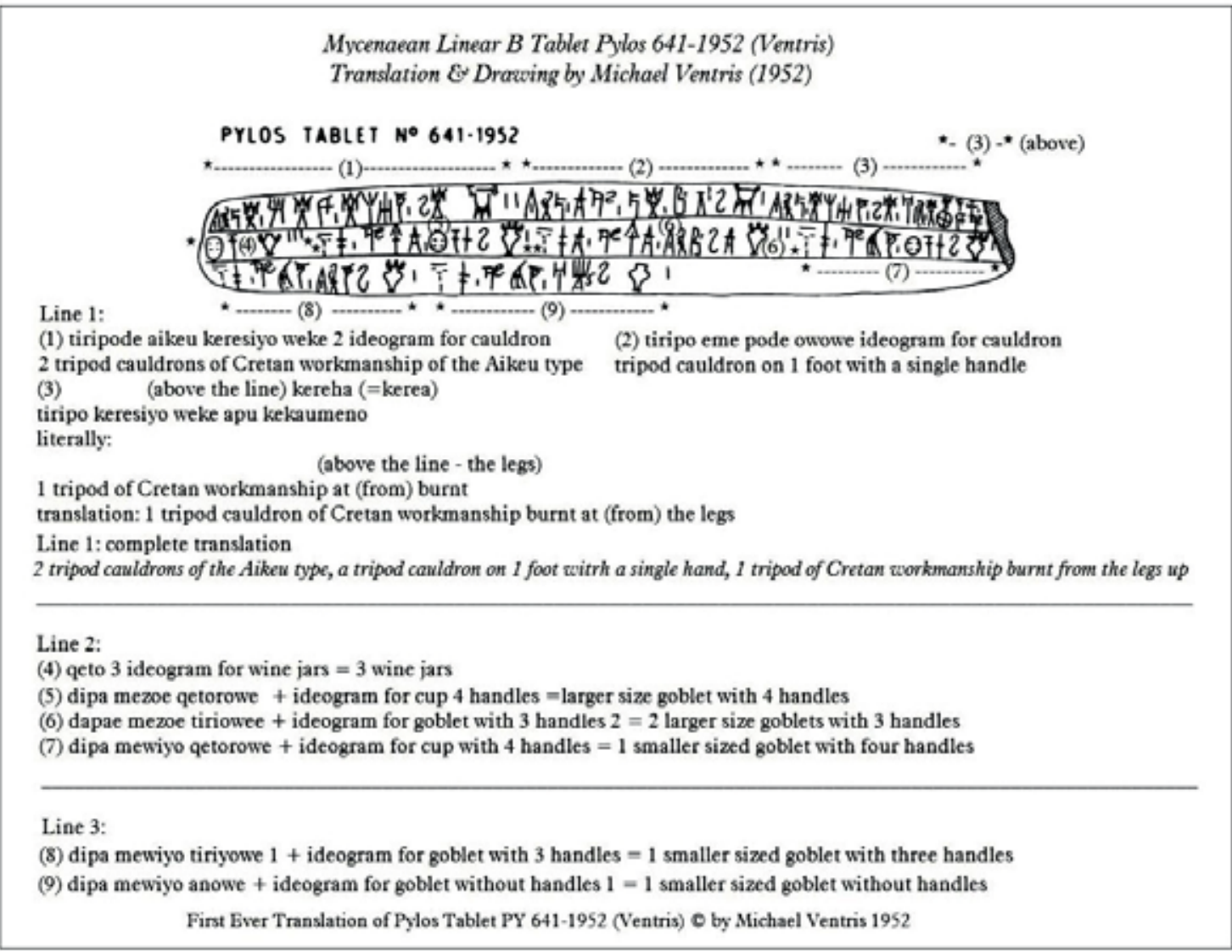

Fig. 6 Drawing and translation of Pylos tablet TA 641-1952 by Michael Ventris (1952)

Enclosed for your information is a copy of Pylos tablet TA 641-1952 (Ventris), which you may find interesting. It evidently deals with pots, some on three legs, some with four handles, some with three, and others without handles. The first word by your system seems to be ti-ri-po-de and it recurs twice as ti-ri-po (singular?). The four-handled pot is preceded by qe-to-ro-we, the three handled by ti-ri-o-we or ti-ri-jo-we, the handleless pot by a-no-we. All this seems too good to be true. Is coincidence excluded?

You can see for yourself that he can scarcely contain his excitement in actually being able to spell out the entire text of the tablet, which he had no choice but to interpret as being in Greek, however clumsy or archaic.

The Decipherment of Pylos tablet TA 6411952:

Armed with this running text in Mycenaean Greek, Michael Ventris was then able to forge ahead with his truly remarkable decipherment of the tablet, which reads as follows (Fig. 6).

His translation was so convincing that he immediately won over the support of the vast majority of linguistic researchers then struggling to decipher the syllabary ${ }^{9}$. They simply had to admit its authenticity. He had cracked the script. It was Greek, at the very least proto-Greek, or perhaps even the earliest known ancient East Greek dialect, which in effect it soon proved to be. It was promptly dubbed Mycenaean for the great civilization which it was representative of.

Ventris' own translation, the very first ever of this justly famous tablet, is highly revelatory.

9 These included Carl Blegen himself, Prof. John Chadwick, who was utterly convinced of the authenticity of Ventris' decipherment, Emmett L. Bennett, Prof. M.S. Ruipérez, Prof. P. Chatraine (Paris) \& the Hellenic Society, now known as the Society for the Promotion of Hellenic Studies (U.K.) http://www.hellenicsociety.org.uk/ See 8. above, pp. 84-85 


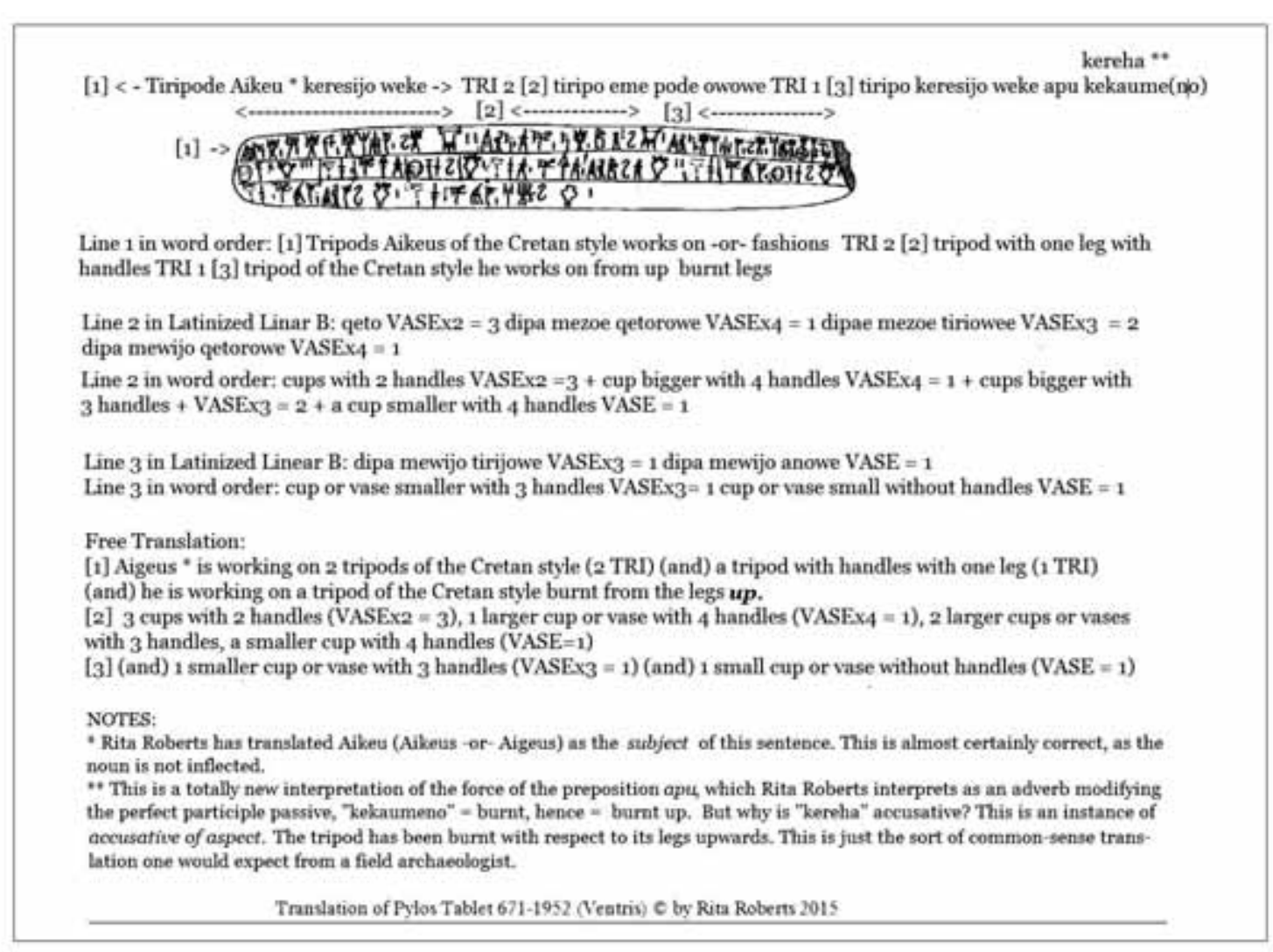

Fig. 7 An archaeologist's thoroughly researched translation of Pylos tablet TA 641-1952 (Ventris) (2015)

Even with reference to it alone, we can draw the following conclusions with confidence.

1. On this Linear B tablet alone there appear no fewer than 5 ideograms for vessels (tripods, cups, vases, amphorae and pithoi), which is to say $16.7 \%$ of all 30 ideograms for vessels in Linear B (see Table 1 supra). That is an impressive showing for just one tablet!

2. The diversity of the ideograms for vessels on this tablet alone is equally striking. All five are different, while those for vessels other than tripods, i.e. amphorae, cups, vases or pithoi (for the storage of olive oil or wine) reveal marked differences from one another. Ventris' decipherment makes this plain.

3. The emphasis which the scribe places on the varying sizes of the cups, vases, amphorae or pithoi as expressed through the ideograms inscribed on this tablet is of great significance. It certainly mattered at lot, not only to him, but to all Mycenaean scribes, regardless of site, because these distinctions were critical with reference to items in inventories of vessels which all Minoan/Mycenaean palatial establishments kept strict close track of.

4. It is quite clear from even this single tablet focusing on vessels in Linear B that the scribe, and indeed all the scribes indentured to their respective palatial administrations, were experts duty-bound to classify all vessels they kept such close track of by (a) size (b) class \& (c) type. The distinctions made by size overlap with those made by class and type, and in fact are a function of the latter two. From the evidence drawn from extant tablets at Knossos and Pylos alone, their palace administrations demanded a strict account of all transactions related to the measurement by size, classification and typology of all vessels and pottery of any description whatsoever in their manufacture, dissemination and trade (export and import) and in their rôle in commercial and religious transactions in the Minoan/Mycenaean 


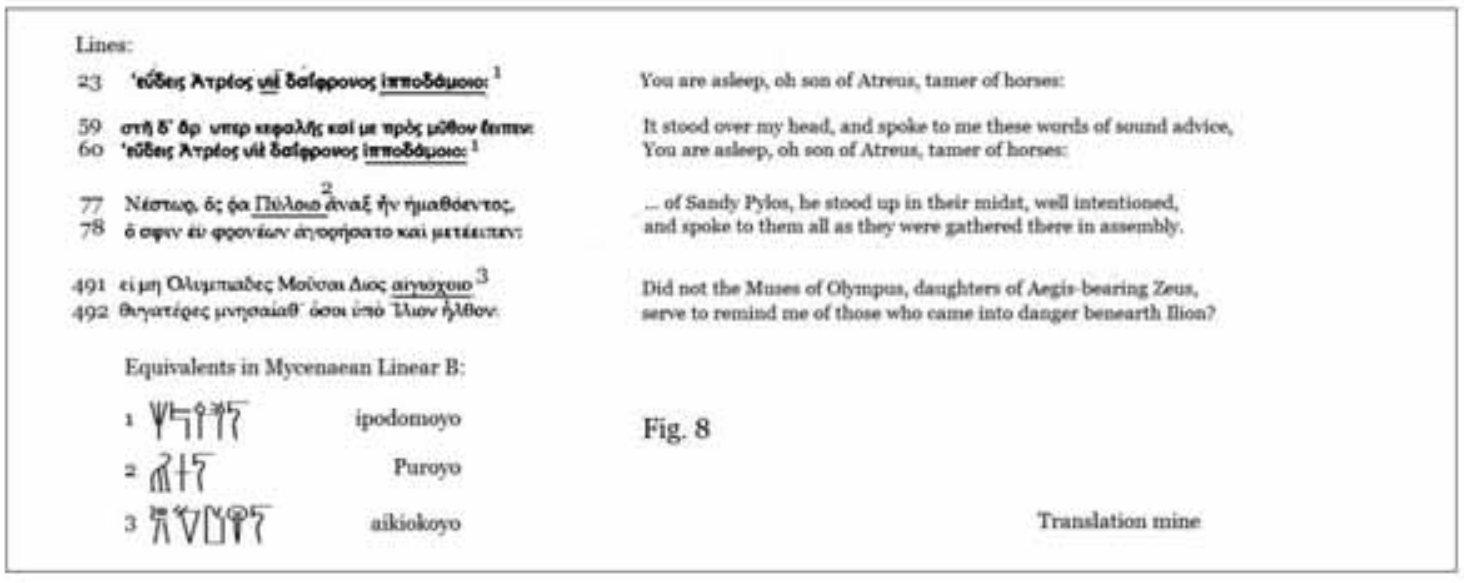

Fig. 8 The archaic Mycenaean genitive in -oio- in The Catalogue of Ships, Iliad, Book II

social economy. Records abound. And what was true for Knossos and Pylos must have also been the case for Chania, Phaistos, Zakros, Mycenae, Tiryns, Orchomenos, Boeotian Thebes, Athens and all other centres of Minoan/Mycenaean economic intercourse.

But if Ventris' decipherment of Pylos tablet Py 641-1952 is revelatory, that of Rita Roberts $(2014)^{10}$ is considerably more so. Let's take a good close look at her translation, and see what further significant conclusions we can draw from it. In Ventris' first translation, occasional errors were made, but these are understandable, given

10 Rita Roberts is an archaeological ceramicist whose overall pottery analysis studies range from the Neolithic period to the Bronze Age, Iron Age, and from the Roman to the Medieval to post Medieval. She was first employed in England by the Hereford and Worcester County Council 'Archaeology Section' from 1981 to 1992, assisting with finds from archaeological sites in Droitwich, Hanbury Street, Friar Street and Upwitch, where she was involved from the beginning of the excavation with analysis of all the pottery which ranged from the Iron Age to Roman and Medieval, and with other material finds such as flint, bones and Roman glass. After retiring to Crete, Greece, she worked on Minoan pottery from the archaeological sites of Mochlos, Petras and Gournia and in conservation at the laboratory of the Institute for Aegean Prehistory Study Center for East Crete from 2003 to 2014. She has also assisted with finds of skulls and bones from the cave burial site at Charalambos. Mrs. Roberts learned to master Mycenaean Linear B from the present author. that his was the first attempt ever at decipherment of such a long tablet in Mycenaean Linear B. In fact, under the circumstances, it is amazing that Ventris did not make more errors, or perhaps not so amazing at all, Ventris being the genius he was. Later translations attempted to recast the opening phrase of the tablet, but they too are not truly satisfactory. Rita Roberts' translation sets out to rectify such errors, as illustrated here (Fig. 7).

NOTE: In this translation, the designations TRI, VASE, VASEx2, VASEx3 \& VASEx4 signify tripod, vase with no handles, kylix vase with two handles, kylix vase with three handles \& a large vase or vessel with multiples of four handles (pithos).

Her translation makes eminent sense. An earlier translation which would have it that Aigeus the Cretan would bring the tripods makes little or no sense. To whom and more to the point, why on earth would he be bringing any vessels to anyone, unless he were a middleman in the economic infrastructure of the pottery production industry? Yet in so far as I am aware, there is no direct evidence in research literature drawn from extant tablets in Linear B of middlemen in any sector of the Mycenaean economy. Additionally, the second translation interprets keresiyo as nominative, which is patently impossible, since the most archaic form of the genitive, terminating with iyo (or ijo) in Mycenaean Greek, is still relatively 


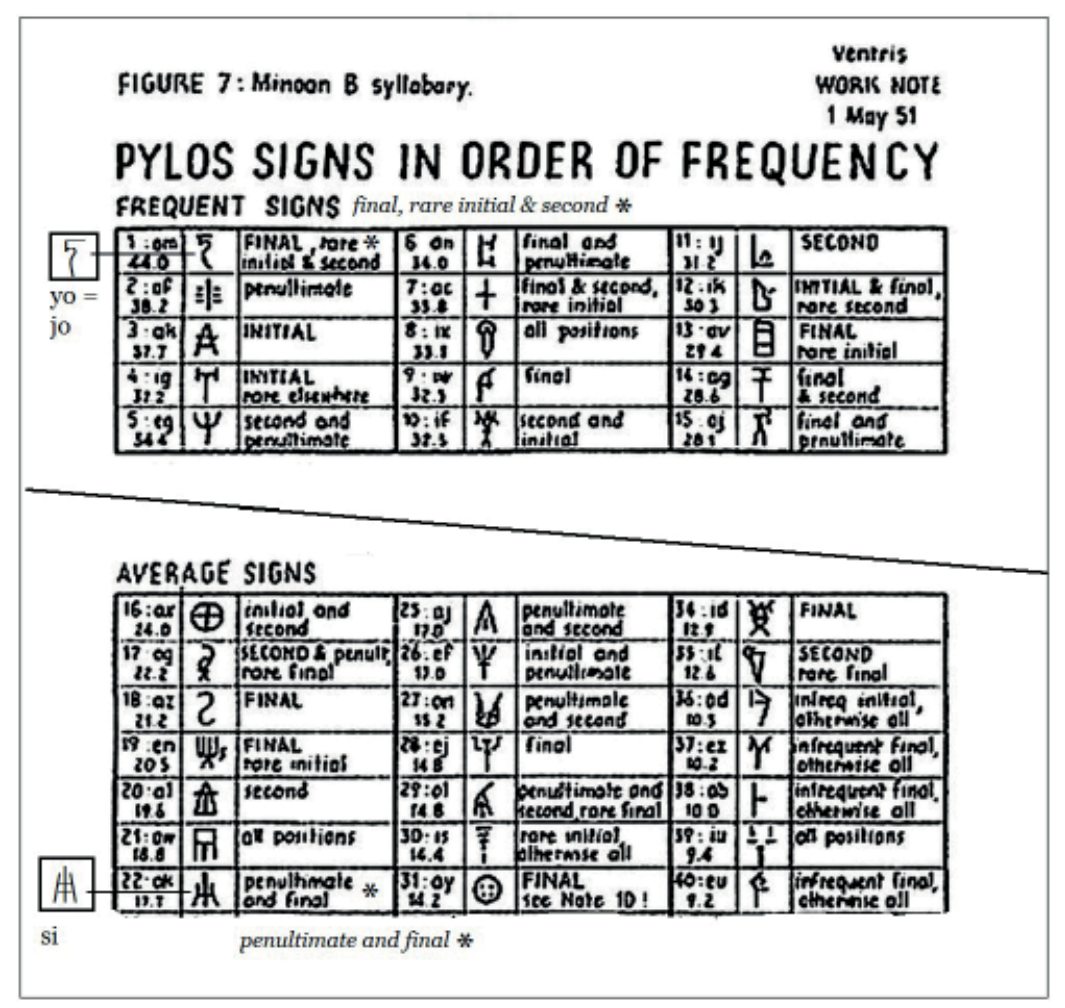

Table 3 Pylos signs (syllabograms) in order of frequency, Ventris Work Note 1 May 1951

commonplace in The Catalogue of Ships of Homer's Iliad, some six to seven centuries later, as illustrated in these instances from my own translation here (Fig. 8)

It is extremely unlikely keresiyo modifies Aikeu. But there still remains another possible rendition of the opening phrase. It could be set in the genitive absolute. If this is the case, then the phrase might mean something like, "Aigeus (the potter) has 2 tripods of the Cretan style in stock." Linear B tablets frequently cite the name of the agent (subject), but rarely supply the verb connecting it with the object, although in this somewhat exceptional case the object is specified tiripode (accusative plural). As I discovered in my thorough-going research into some 3,000 extant tablets from Knossos which I carefully read throughout the latter half of 2013 and all of 2014, this phenomenon is particularly striking on scores of tablets on some 700 agricultural tablets from Knossos citing sheep alone as livestock. Unfortunately, the present study does not offer us the scope to focus on the requisite in-depth contextual analysis of those tablets, however significant the implications of such research are... as they most certainly are.

Nevertheless, the difficulty here is that there is no way of our knowing whether or not the genitive absolute was in common or even occasional use in the Mycenaean Greek dialect, given its great antiquity. I for one remain doubtful. For this reason and this reason alone, Rita Roberts and I have decided to settle for the translation you see above. And here we recall the point I made earlier over Sir Arthur Evans' fortuitous insight: "At most, a few signs are notably frequent as terminals; they seem to replace each other in the same grammatical position and are, therefore, suffixes adhering to the stem, ..." Instead of downplaying this momentous discovery of his, we can readily make the following sound observations firmly based on Michael Ventris' own meticulous statistical compilation of the frequent repetition of two highly significant terminations in Mycenaean 

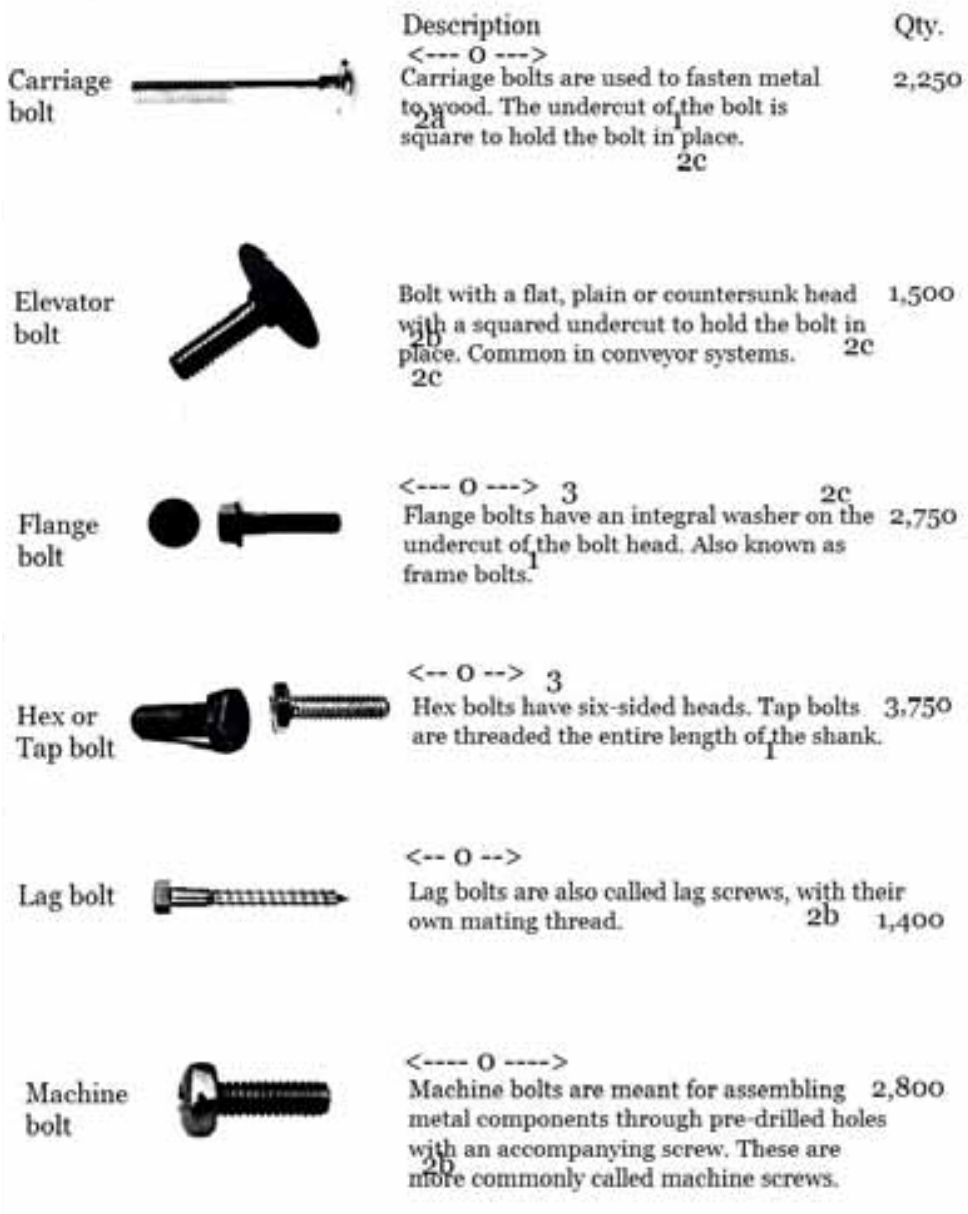

Plow bot

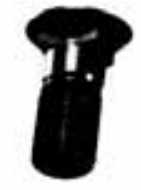

With a cougtersunk head, a square shank, 1,350 and a unified thread pitch, plow bolts are durable and common in construction devices. $2 \mathrm{c}$

\section{Square}

head bolt

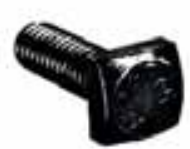

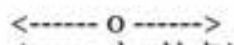

A square head bolt is a four-sided bolt with a machine screw.

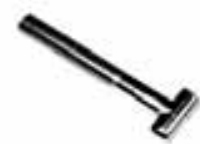

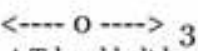

A T-head bolt has a T-shaped head which 1,250 can fit intg glot or can be gripped easily with a wrench.

NOTES re. grammatical relations: $0=$ nominative $1=$ genitive $2 \mathrm{a}=$ dative $2 \mathrm{~b}=$ instrumental $2 \mathrm{c}=$ locative $3=$ accusative. If this inventory were in an inflected language with any or all of these cases, the inflections would be clearly identified. Modern inflected languages include German, Greek \& Russian.

Table 4 Richard's Hardware, Ottawa, Ontario, Canada: Inventory of bolts in stock 
Linear B on the tablets at Pylos alone, these being the genitive singular and the dative plural, as illustrated here in Table 3, an excerpt from Ventris' "Figure 7: Minoan B Syllabary: Ventris WORK NOTE 1 May 51": (Table 3)

One glance at Ventris' grid of 1 May 1952 lends full and unequivocal credence to Evans' own observations. The termination jo genitive singular, yo or if you like jo (Linear B Latinized), accounts for no less than $44.0 \%$ of all syllabograms on all extant tablets from Pylos! That is a staggering frequency. Evans had it bang on. Now take the syllabogram si (Linear B Latinized), which is the standard Mycenaean (as well as Homeric) termination for the dative plural. While tagged as a sign of average frequency, it still accounts for $19.7 \%$ of all syllabograms on all extant tablets from Pylos. Just what am I driving at? These statistics are astonishingly revealing. On the one hand, Evans is entirely on the money when he asserts that "there is little trace of an organized system of grammatical suffixes, as in Greek." But then he misses the point entirely, failing to recognize the extreme significance of the fact that these two syllabograms alone account for $63.7 \%$ of all syllabograms on extant tablets from Pylos! Just what can this imply? A very great deal. It just so happens that these two terminations, i.e. these two cases predominate over all others on all extant tablets in Mycenaean Linear B, inclusive of all verbal endings. Why so? We need only turn to examples of modern inventories to glean the reason. Modern inventories in inflected languages such as Greek, German and Russian, usually in the form of spreadsheets or itemized lists, place all serialized items in the nominative singular or plural only. The two oblique cases which figure prominently and often exclusively on inventories in inflected languages, ancient and modern, are the genitive singular and dative/instrumental/locative singular (sometimes) and plural (often). Table 4 , a standard inventory of bolts in a fictitious Canadian hardware store in Ottawa illustrates my point unequivocally.
Even though this small inventory is in English, the first thing we notice is that, with the exception of 2 entries which have a direct object, each bolt is itemized as subject with the copulative verb "to be". This is the prime characteristic of all inventories, ancient and modern. Items either stand alone, falling quite outside of the structural imperatives ${ }^{11}$ underlying sentence or phraseological constructs, or they are simply complemented by the copulative "to be". Hence, in any inflected language, ancient or modern, itemized elements are almost always uninflected (nominative singular or plural). We must keep this point firmly mind at all times if we are to accurately grasp the essential underlying structure inherent in all inventories, ancient or modern.

Secondly, all of the prepositional constructs in this English language inventory make it abundantly clear that if it were compiled in any ancient or modern inflected language, such as German, Greek or Russian, the 2 cases which would appear with the greatest frequency are in fact the genitive and dative/instrumental/locative. In other words, even in those instances where cases enter into the equation in inflected languages, ancient or modern, the words or phrases are in almost all cases inflected solely as a function of the main entries in the nominative which they modify, and nothing more. So the nominative is dominant over all inflections, without few or no exceptions. All this boils down to one fundamental point: inventories are not sentences, because they are never meant to be. Hence, complex inflectional constructions are the exception rather than the norm. Certainly, the highly refined and elegant grammatical structuralism so typical of ancient classical Greek, as attested in the prolific prose of the Attic dialect, is utterly absent from Mycenaean Greek inventories in Linear B. It cannot be otherwise.

In the almost total absence of sentence structure in Linear B, what then are the predominant characteristics of Mycenaean Greek inventories in

11 Wikipedia: Structural Linguistics https://en.wikipedia. org/wiki/Structural_linguistics 


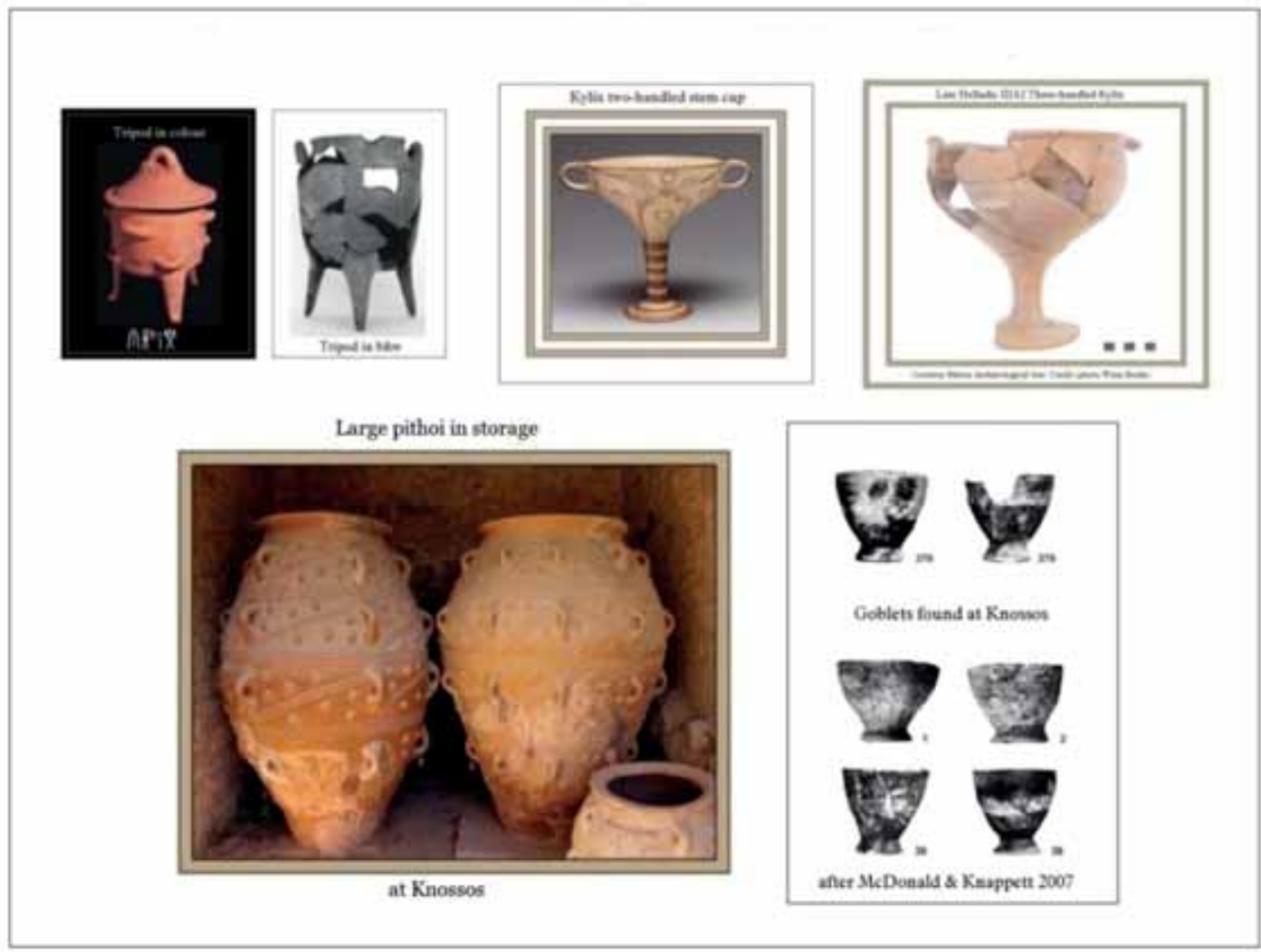

Table 5 Types of vessels mentioned on Pylos tablet TA 641-1952 (Ventris)

Linear B? To summarize, these are, to a fault,

1. extremely repetitious text, characterized by highly formulaic stock phrases;

2. the presence of the uninflected nominative in almost all entries, with exceptions being extremely rare;

3 . the relatively frequent presence of the genitive and dative/instrumental/locative singular and plural, but only as adjuncts to the uninflected nominative of their primary itemized elements;

4. the rarity of the accusative case, for lack of direct objects on the vast majority of extant tablets.

These observations serve to underscore the fact that the accusative in Mycenaean Linear B comes close to being absent from the inventories on extant tablets, regardless of provenance. This goes along way to clarifying why it is so damnably difficult to reconstruct declensions in Mycenaean Greek. Inventories are not concerned with who did what to whom (singular), in other words, they are unconcerned with the notions of the inflectional syntactical constructs, nominative-verb-accusative-dative singular as posited by structural linguistics ${ }^{11 b i s}$ of the twentieth century. They are merely itemized lists of objects or commodities where the numerical count is nominative singular (units) or plural (multiples) of the aforementioned objects of commodities (genitive), with the additional proviso that such commodities may serve a useful purpose for something to (both $d a$ tive) certain agents or sectors of the Minoan/Mycenaean economic infra- and superstructure. To expect otherwise is to ask for pie in the sky.

Pylos tablet TA 641-1952 serves a perfect example illustrative of the repetitive use of the genitive singular in an itemized inventory.

Yet Mrs. Roberts' perspicacious decipherment brings a great deal more to bear on the decipherment. As an archaeologist, she has succeeded at 
last in doing what no one has done before: she has specifically identified the types of each and every one of the vessels inventoried on this tablet viz: (Table 5)

It is worthwhile noting it this regard that Mrs. Roberts has cited the ground-breaking findings of McDonald and Knappett (2007) ${ }^{12}$ since they were the first to pointedly draw attention to the fact that they were explicitly interested in unearthing the simple, unadorned earthenware handle-less goblets no archaeologists prior to them could even bothered with a major oversight unworthy of the field of professional archaeology. It is after all these selfsame goblets which Pylos Tablet PA 641-1952 (Ventris) itemizes as anowe, meaning without handles.

Her well-honed investigative skills as an archaeologist have thus facilitated a ground-breaking translation, the first ever which clearly reflects the actual meanings the scribe assigned to each vessel. It cannot come as any surprise that the scribes, who after all were assigned the sole task of inventorying down to the very last detail the palatial assets at each Mycenaean centre of any economic import, must not have stinted in their efforts to ensure that their inventories, regardless of sector, rendered a totally accurate account of all items in the local economy. So the text can now be translated with significantly greater accuracy as:

Aigeus is working on 2 tripod cauldrons of the Cretan style, a tripod with handles on one remaining * leg, on a tripod of the Cretan style burnt from the legs up, on 3 kylix cups with 2 handles, on 1 (olive oil or wine) pithos **, on 2 larger kylixes with 3 handles and one small goblet with no handles.

The first observation we should make here is that of the deliberate insertion I have made of

12 Knappett, Carl, Mathioudaki, Iro \& Macdonald, Colin F. 2007

Stratigraphy and ceramic typology in the Middle Minoan III palace at Knossos, document in preparation: 9-19 https://www.academia.edu/2950003/Stratigraphy_and_ Ceramic_Typology_in_the_MM_III_Palace_at_Knossos (Note: Apparently this paper has never been published in print) the word "remaining". It is there in the English to make it quite clear that the other two legs are missing... two legs because the tripods unearthed at Knossos all had three (see illustration above). Next, it is obvious to an observant reader that this is a translation into a version of Greek much later than Mycenaean, possibly even as late as classical Ionic or Attic, since the word for pithos, which is nowhere attested on any extant tablet in Linear, almost certainly did not exist in Mycenaean Greek. However, it is apparent to anyone who is an archaeologist that a pithos **, such as any of those found at Knossos, as illustrated above is by default "a (much) larger vase with 4 handles". Or is it just 4 handles? More to come on that sticking point.

Likewise, the 2 and 3 handled vases are almost certainly kylixes. Again, the word kylix (a type of drinking vessel) would likely not have been in use in Mycenaean Greek. Finally, no fewer than 6 small drinking vessels or goblets were unearthed at Knossos, after McDonald and Knappett (2007) (see supra). So as for the small vessels with no handles, we can pretty much rest assured that the appropriate translation is "small goblets", with the emphasis on small, because the text on the tablet makes this explicit. In the final analysis, Mrs. Roberts' translation would surely read as we have given it here. However, it still is incumbent upon us to render it as an accurate reflection of the original Mycenaean, and in that context it reads as follows:

Aigeus is working on 2 tripod cauldrons of the Cretan style, a tripod with handles on one leg, on a tripod of the Cretan style burnt from the legs up, on 3 smaller cups with 2 handles, on 1 larger vase with 4 handles, on 2 larger cups with 3 handles and one small goblet with no handles.

This is effectively the original Mycenaean Greek version of the classical translation I have given above. For all intents and purposes they say exactly the same thing.

Yet, there still remains one outstanding difficulty, and it is a real stickler. Why does the ideo- 
gram for a pithos, which has not four, but multiples of four handles on its sides, show only 4 handles on top? If we take a good hard look at the photographic illustration above, what do we see? - not one but two giant pithoi from Knossos, one sporting 24 and the other 32 handles! In other words, we have 6 and 8 multiples of four. To date, there is not a single reference to this actuality anywhere in the archaeological literature on Minoan-Mycenaean vessels, because no one has bothered to pay any attention to it. But there we have it, staring us squarely in the face. I specifically had to make a request to my colleague, Rita Roberts, in Crete, to verify my calculations. They in fact turn out right on the money ${ }^{13}$.

This might pose a problem for those archaeologists and linguists in Mycenaean studies who take ideograms to literally represent the objects they portray, but such is scarcely the case, neither in Mycenaean Greek nor in any other ancient syllabary or hieroglyphic script, where great liberties were taken for the sake of practical functionality and standards of formulaic uniformity enforced by the scribal guilds. It would have been downright impossible for the scribes to portray a multiple series of handles in three dimensions on the side of a pithos calqued onto a two-dimensional ideogram. In other words, the ideogram for pithos is not only standardized, it is formulaic, just as all ideograms are, and in addition, as the vast majority of Mycenaean Greek texts are. To ram the point home, we clearly observe on this single tablet that the text "of the Cretan style" is serially repeated, as are its attendant ideograms, twice in a row. Such a solution was not only practical but clear cut to themselves, as scribes. It does

13 Mrs Roberts asserts, "Our librarian at Knossos has seen them (the pithoi) in situ and as she remembers there were three more rows of handles at the back so that makes 32 handles in all. So many handles were there for ropes to be passed through for ease of transportation." Mrs. Roberts is referring to the fact that the librarian was able to see 1 set of 4 handles from the front, but that by looking all the way around the largest pithoi, she saw 3 more sets of 4, hence, the total of 32 . Moreover, slightly smaller, but still quite large, pithoi, have 3 sets of 4 handles, for a total of 24 . not matter one jot whether we, in the twenty-first century, find this strategem counter-intuitive. My point, the very same I made in my presentation, "The Rôle of Supersyllabograms in Mycenaean Greek" at The Third Interdisciplinary Conference, “Thinking Symbols", June 30-July 1 2015, at the Pultusk Academy of the Humanities, simply is this, and I quote:

They (supersyllabograms) are there because the scribes, as a guild, all understood perfectly well that each and every supersyllabogram always meant one thing and one thing only to them in its proper context. The very notion of future interpretations of what was obvious to them as accountants would have never entered their minds. But we owe it to ourselves to decipher as many supersyllabograms as we can. Otherwise we learn nothing of value to the field of historical linguistics in Mycenaean Linear B.

And what applies to supersyllabograms (see infra) equally applies to formulaic Mycenaean text and to ideograms in all sectors of the Mycenaean economy and society. In effect, the Mycenaean scribes carried these 3 formulaic practices to the extreme on some 800 of 3,500 (22.86\%) extant tablets from Knossos alone, and on all of the extant tablets concerned with pottery from Pylos. To summarize, Mycenaean Greek texts in Linear B are formulaic on at least four counts:

Mycenaean text on extant tablets is routinely formulaic to the extreme.

Mycenaean ideograms are likewise formulaic in in all instances, completely standardized, which is to say, invariable, on all tablets at all sites regardless of provenance (Knossos, Pylos, Mycenae and Thebes)

Linear B homophones, a.k.a. logograms, are also practically invariable, with very few minor exceptions.

Supersyllabograms, which are rampant on extant tablets from Knossos, appearing on some 700 out of 3,500 relatively intact tablets (exclusive of fragments), are also invariably standardized. I shall address the massive key rôle supersyllabo- 
grams play in Mycenaean Linear B tablets in the last section of this article. Supersyllabograms are my own definition for what previous researchers have all tagged as "(surcharged) adjuncts". While most supersyllabograms appear to be mere "adjuncts", none really are, and many are not adjuncts at all. This discovery of mine is nothing short of revolutionary to the field of decipherment of Mycenaean Linear B, as we shall shortly see.

But there is more. Ideograms, which frequently appear on the vessels tablets from Pylos and Knossos alone, and which proliferate on tablets in all sectors of the Minoan-Mycenaean economy, are quite often more than mere ideograms. Just as photographs of each line item often appear in any modern inventory such as our fictitious hardware inventory of bolts, as we have already seen, ancient inventories, at least those in Mycenaean Linear B, used ideograms as markers or subject headings to unequivocally flag the contents of each tablet on which they appeared. These ancient ideograms are two-dimensional images superimposed as elemental constructs on the tablets. They are equivalent to the three-dimensional (digital) photographs serving the same purpose in modern inventories. In this light, it becomes easier for us nowadays to understand why the Linear B scribes were forced to resort to depicting a maximum of 4 handles on the ideograms for the largest vessels they inventoried. In the absence of three-dimensional constructs, they had no other choice. An ideogram with 8 , let alone 16,24 or 32 handles, would have looked messy at the very least, and would have been totally unwieldy in any case. But this still leaves us with one final question. Why did the scribes superimpose the 4 handles on top of the largest vessels they wished to portray via ideograms? I can see at least three reasons: (a) since they did so for kylixes with 2 and 3 handles, even though these too sometimes also had handles on their sides, then why not for pithoi as well? (b) to ensure that the agreed upon ideograms were as simple and streamlined as possible so that all scribes could incise them with relative ease and (c) for the sake of formulaic uniformity, all of which practices are common in almost all ancient hieroglyphic scripts, and in syllabaries sporting ideograms.

To summarize, the commonplace functionality of ideograms as subjects speaks a great deal to the sophistication of Mycenaean Linear B, a syllabary considerably more complex than most other ancient scripts, even the later alphabetic, such as Greek and Latin. That this is the case becomes even more obvious as we turn our attention to the most striking phenomenon of them all on so many hundreds of Linear B tablets. I speak of the widespread presence of supersyllabograms.

An introduction to supersyllabograms in the vessels and pottery sector of Mycenaean Linear B:

Recent research leading to the discovery of supersyllabograms in Mycenaean Linear B:

As far as I can tell, Enriqueta and Tina Martinotti ${ }^{14}$ are the sole researchers who have, to date, come to the very brink of isolating and defining supersyllabograms. It is expedient to review the real substance of their findings, through the excerpts in their study which follow (my English translation follows the original French text):

Commençons par analyser «l'axiome» selon lequel le Linéaire B est une «écriture double» utilisée pour écrire des listes comptables. Il s'agit d'un axiome que (sic - qui) n'a de correspondance dans aucun autre système syllabaire... passim... D'autres signes, par groupes de deux à sept, qui précédent (sic - précèdent) ces idéogrammes, furent interprétés comme des «mots»... passim... Aujourd'hui on considère que le Linéaire B est une écriture tout à fait différente des autres systèmes syllabaires - elle utiliserait des signes phonétiques et des signes «idéographiques», ensemble ou séparément, pour écrire deux fois la même chose, l'une étant la "chose», l'autre étant un «aide mémoire» qui répète ce qu'est la «chose» (en italiques selon moi-même). Un sys-

14 Martinotti, Enriqueta et Tina. 2008

Linéaire B; le préjugé comptable et pictogaphique d'un syllabaire logographique, phonologique et polysémique, hal 00311652, version 3. 10 Sept., 2008: unpaginated 


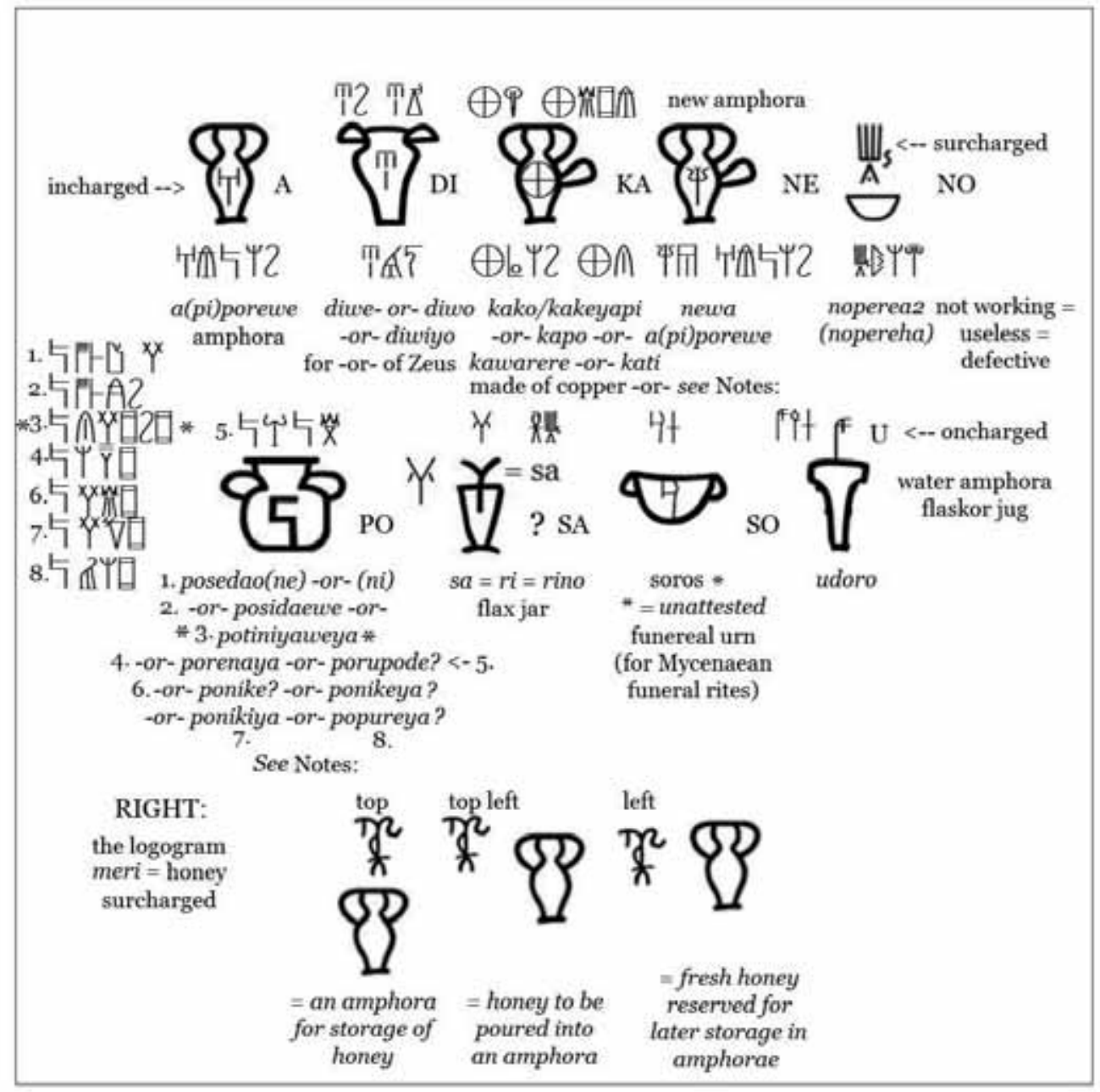

Table 6 Supersyllabograms in the vessels sector in Mycenaean Linear B

tème donc de type «double», unique au monde. Et qui, en outre, serait la seule écriture connue à usage exclusivement administratif et comptable... passim... L'idéogramme est susceptible d'une lecture par ce qu'on peut appeler rébus, par lequel on signifie un mot en se servant d'un logogramme dont la lecture phonétique révèle ce qu'on veut faire entendre. Le rébus peut engendrer aussi des variantes polysémiques ou homophoniques... passim... Lorsque des syllabogrammes paraissent en série, cela ne conduit pas nécessairement à un mot de manière absolue. Chaque syllabogramme est aussi un mot (en italiques selon moi-même). Pour les distinguer il faut chercher les significations de chaque signe en tant que lexème, en se servant de la polysémie comme cela se fait dans l'interprétation des autres systèmes syllabaires.
Let us begin by analyzing the "axiom", according to which Linear B is defined as a "double script" used to write accounting inventories. As this axiom would have it, this phenomenon corresponds in no way to any other syllabary system... passim... Other signs, preceding ideograms in groups ranging from two to seven, have been interpreted as being "words"... passim... Today, we usually consider Linear B as a script totally unlike other (ancient) syllabic systems - it alone would appear to employ phonetic and "ideographic" signs, both in conjunction and separately, to write out the same item twice, one instance being the "item" in and of itself, the other serving as an "aide-mémoire" to it, which essentially recounts what the "thing" means (italics mine). So we have here a "double" system, unique in the world (past 


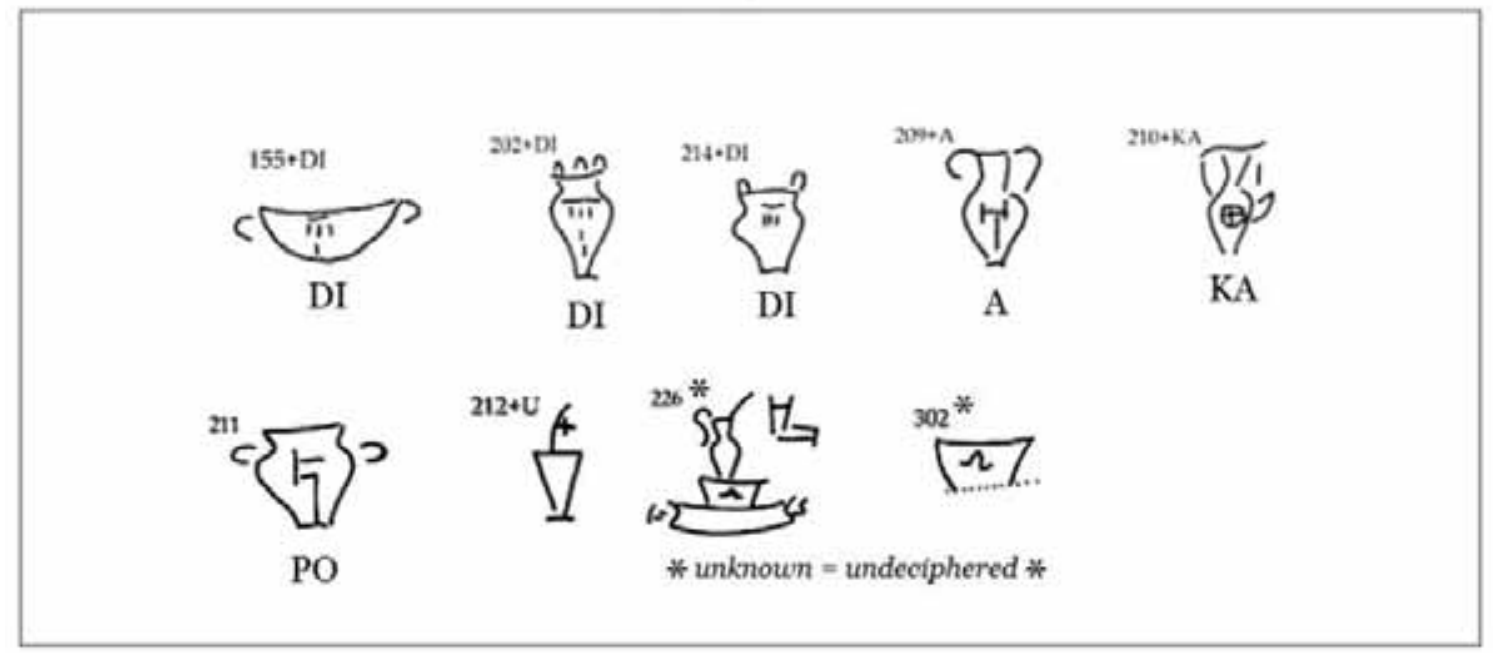

Table 7 Facsimiles of supersyllabograms for vessels in Mycenaean Linear B (mostly from Knossos)

and present), which besides would appear to be the only script ever known for use in the administrative and accounting sector exclusively... passim... Each ideogram is subject to a reading which we can typify as being what is commonly called a rebus, a procedure whereby we utilize a logogram to signify a word. The logogram facilitates a phonetic reading revealing what the scribe wishes to convey. A rebus is also able to give rise to polysemic and homophonic variations... passim... The mere fact that syllabograms do appear in series does not necessarily imply absolute reference to a single word. Each syllabogram is also a word (italics mine). In order to draw distinctions among them, it is necessary to ferret out the meanings of each sign as a lexeme in and of itself, with reliance on polysemics as they apply equally to the interpretation of other syllabary systems ${ }^{14}$.

So now the burning question is, what on earth are supersyllabograms? Although the Mycenaean scribes never called them that, any more than they referred to syllabograms as such, they were perfectly aware at the conscious level what both of these phenomena constituted. This excerpt from our presentation at the Pultusk Academy of the Humanities, July 1, 2015, provides a succinct definition of supersyllabograms.

Now to the question of supersyllabograms. What are they, and what rôle do they play in
Mycenaean Linear B? Some of the tablets I examined had single syllabograms only on them, and no text whatsoever. The question was, I had to wonder - and I mean I really had to wonder - why on earth was there no text and what did all these single syllabograms mean? The answer was not long in coming.... this syllabogram (ze), which is the first syllable of the word zeukos (a pair)... passim... is paired with the ideogram for, guess what, a chariot wheel! So the syllabogram $z e$ is the first syllable of the Mycenaean Linear B word or phrase it symbolizes. That is exactly what a supersyllabogram is, a syllabogram symbolizing an entire Mycenaean Linear B word or phrase.

By default and without exception, all supersyllabograms are the first syllabogram, in other words, the first syllable, of one particular Mycenaean Linear B word or phrase only and none other, which is always strictly dependent on the specific context of the economic sector of the Minoan-Mycenaean economy in which it appears (all italics mine throughout this entire section). Change the context of the economic sector, for instance from the agricultural to the military or the vessels sector, and you automatically change the meaning of the supersyllabogram, with very few exceptions (the syllabogram ne (Linear B Latinized), invariably meaning newo (masc.) newa (fem.) (Linear B Latinized) or "new" in all sec- 


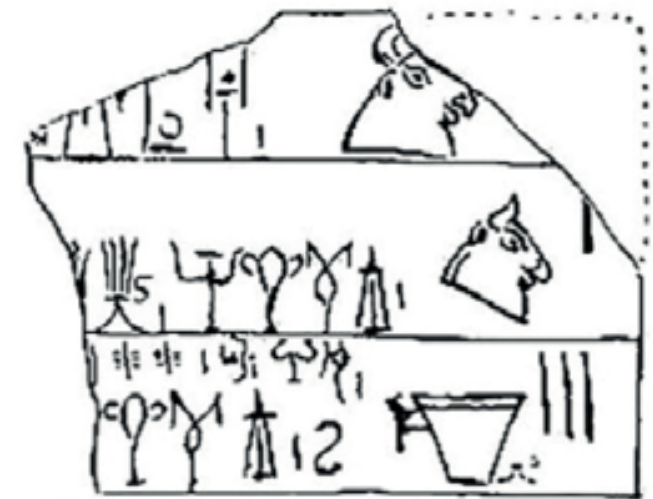

$872 \mathrm{M} \circ 01$ (2xt)

Line 1: ? raa (ideogram) libation vessel

2: ? no. neqasapi (ideogram) libation vessel 1

3: ? tete. kuruso (ideogram) Nestor's style cup 3

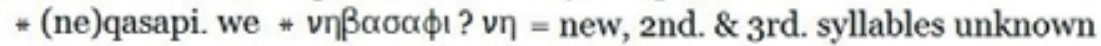

Translations: 872

1 raa? libation vessel

2 no? newly ? 1 libation vessel

3 newly? 6
874 403 handled kylixes dedicated to the god Zeus -or- to the goddess Potiniya

Fig. 9 The supersyllabogram DI in the vessels sector of the Mycenaean economy

tors being the most conspicuous). All such single syllabograms, without exception, appear either (a) adjacent to the ideogram or (b) inside the ideogram they qualify, and (c) they repeat themselves over and over, like clockwork. Supersyllabograms which appear adjacent to their ideograms are invariably associative, while those which appear inside their ideograms are invariably attributive. Associative supersyllabograms, which appear primarily and in droves in the agricultural sectors of the Minoan-Mycenaean economy, are either surcharged, appearing to the top right or occasionally to the top left, or supercharged, appearing right on top of the ideogram they qualify. Attributive supersyllabograms are invariably incharged, bound inside the ideogram they qualify. In this article introducing the phenomenon of supersyllabograms in Mycenaean Linear B, we shall be dealing primarily with incharged supersyllabograms, which are characteristic of the pottery and vessels sector of the Minoan-Mycenaean economy.
In 2014, extrapolating my findings to the vessels sector alone of the Minoan-Mycenaean economy, I wasted little time in identifying and classifying the supersyllabograms-cum-ideograms in the vessels sector alone of the Minoan-Mycenaean economy. There are 10 of them (See Table 6 above).

Two supersyllabograms in particular call for clarification.

The first of these is ka (Linear B Latinized), to which I have assigned four (4) possible variant meanings. The most obvious of these is the first, kako $x \propto \lambda \chi x^{\prime} v$,then kako $x \propto \lambda \chi x^{\prime} v+$ kakeyapi $\chi \propto \lambda \varepsilon i \alpha \phi 1=$ copper. The SSYL (supersyllabogram) $k a$ (supersyllabogram) (Linear B Latinized) could also possibly refer to kapo карто́s $=$ fruit, kararewe $\mathrm{k} \lambda \alpha \rho \varepsilon u ́ S$ = stirrup jar or even

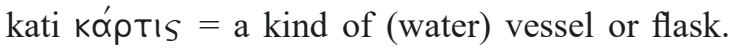
Since the last possibility obviously overlaps with the incharged SSYL $u$ (Linear B Latinized), which clearly designates a water jug, flask or flagon, I am 

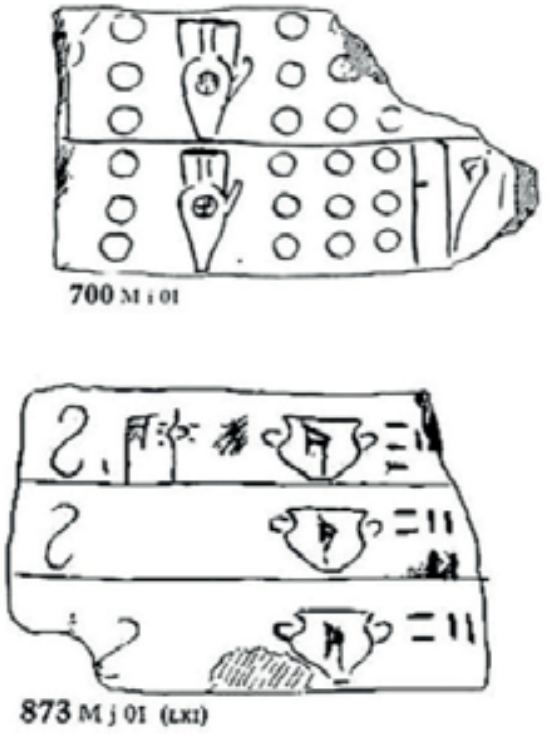

700:

do? 300 (ideogram) amphora, ne

incharged 900

300 (ideogram) amphora, ne incharged 900

dami * 1 ? " $\delta$ áu dat. of $\delta$ áuos village,

municipality

Translation:

do? $300+900$ new amphorae

$300+900$ new amphorae for the village 1 ?

878:

we. udo ? (ideogram) two handled kylix, so incharged $32+$ so $=$ 月 we (ideogram) Ibid. $24 \quad$ 个 cinerary urn Ibid. 22

Translation

6 water? $32+2$ handled kyllixes for funereal rites

6,24 two handled kylixes for funereal rites

6,22 two handled kylixes for funereal rites

Fig. 11 The supersyllabogram $U$ in the vessels sector in Linear B

strongly inclined to dismiss it. While the vessel could be of copper, it is also quite likely that the scribes were referring to the stirrup jar as a vessel type. These latter two possibilities strike me as the most cogent, the last being the most convincing.

Next we have po (Linear B Latinized), which could mean any of the following: posedao(ne) -or(ni) $=$ Posedaon i.e. Poseidon (god's name), posidaewe, referring to a cult probably associated with Poseidon, potiniyaweya (adjectival), referring to a priestess or follower of the Minoan-Mycenaean/ Homeric goddess, Potnia, porenaya, attendants in sacrificial ceremonies, porupode, an octopus, generally on a vase or amphora, ponike, decorated with a griffin or ponikeya, crimson, and finally, popureya, purple. I felt obliged to account for all of these possibilities, since we are confronted yet again with the conundrum, what did the scribes themselves intend it to mean? However, in light of the literature on religious and sacrificial rites in the Minoan and Mycenaean societies, it would appear that the most tenable translation is likely to be potiniyaweya (adjectival/ attributive), referring to a priestess or follower of the Minoan-Mycenaean/Homeric goddess, Potnia, since not only is their religion predominantly matriarchal, but this goddess in particular is frequently referenced. The literature on this subject is abundant (Table 7).

These supersyllabograms as inscribed on numerous tablets on vessels appear here in facsimile. The following 3 illustrations of several tablets in the vessels sector, all from Knossos, more than amply illustrate the power of supersyllabograms. (Fig. 9, Fig. 10, Fig. 11)

Supersyllabograms in the pottery and vessels sector (let alone all others) are so information rich that they call for considerable clarification.

1. Although previous researchers, without exception, have tagged supersyllabograms as "adjuncts" to ideograms, they are in fact far more than merely that. Careful examination of a small cross-section of pottery and vessels from Knossos alone confirms that this is the case, as illustrated above.

2. My translations of even these few tablets reveals this astonishing find: supersyllabograms replace not only single words but often entire phrases in Mycenaean Linear B (see Martinot$\mathrm{ti}^{14}$ supra). In effect, they telescope what would have otherwise been discursive and space-wast- 


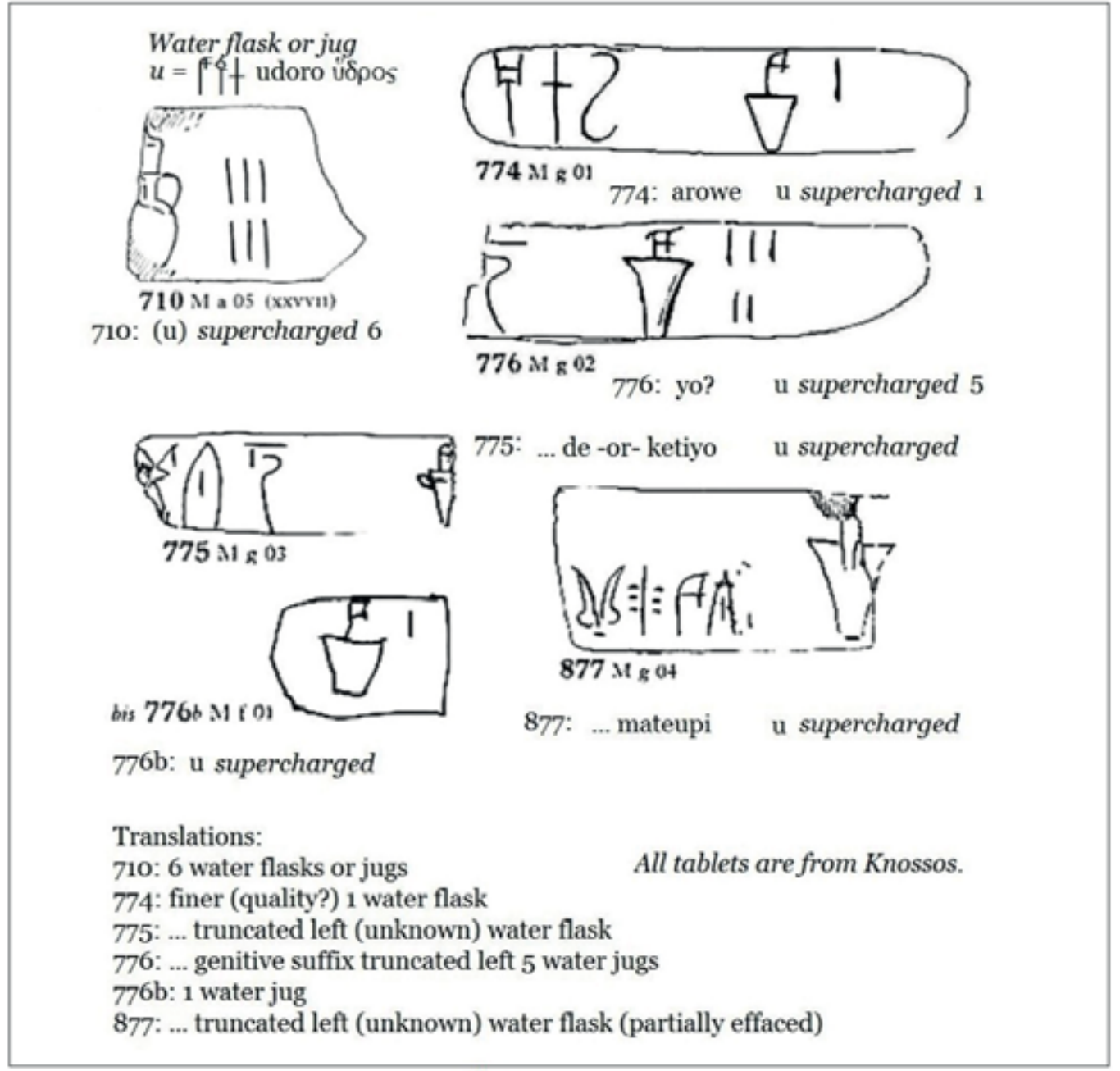

Fig. 11 The supersyllabogram $U$ in the vessels sector in Linear B

ing text on such small tablets into one single element, namely, themselves. In this sense, the supersyllabogram, as a phenomenon, functions as a sort of linguistic ouroboros or uroboros (from the Greek oúpoßópos, tail-devouring snake), an ancient symbol depicting a serpent or dragon eating its own tail.

3. This reveals yet another key characteristic of Linear B tablets which deploy supersyllabograms to replace Mycenaean words or phrases. Supersyllabograms in the pottery and vessels sector alone (as in every other sector of the Minoan-Mycenaean economy) effectively operate as shorthand. This startling discovery sets back the time frame for the first known use of shorthand some 3,300 years from the late nineteenth and early twenti- eth centuries. Once again, Mycenaean Linear B attains a high degree of versatility and sophistication virtually unknown to other contemporaneous scripts, hieroglyphic or syllabogrammatic, inclusive of Arado-Cypriot Linear C, which entirely abandoned ideograms.

4. Yet the most astonishing characteristic of supersyllabograms in the pottery and vessels sector of the Minoan-Mycenaean economy is this: the majority of them are attributive, and dependent on the ideograms they qualify. Attributive dependent supersyllabograms always appear inside the ideogram which they qualify, never adjacent to it. They always describe an actual attribute of the ideogram. For instance, the syllabogram $\boldsymbol{a}$ inside the ideogram for a vessel with 2 handles is the first 


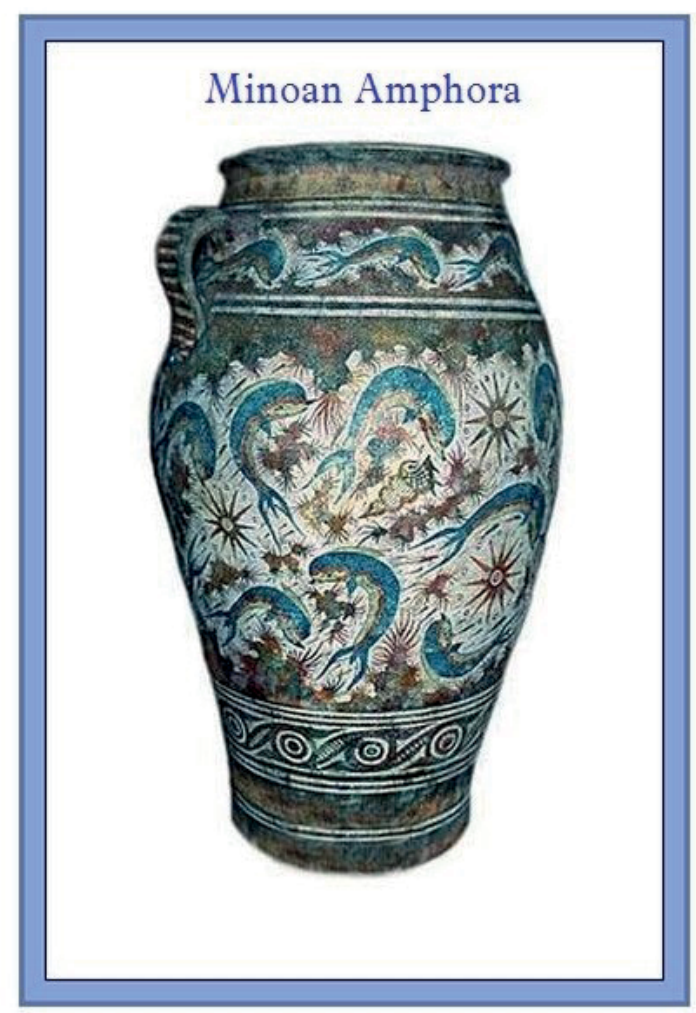

Fig. 12 a Minoan dolphin vase - 2nd Millennium BCE marine style, the most distinctive of all Minoan pottery with naturalistic depictions of dolphins, octopuses and other sea creatures

(Minoan Art and civilization, Pinterest)

syllabogram, i.e. the first syllable of the Mycenaean word apiporewe, unequivocally identifying the vessel as an amphora. But why even bother noting this, when it is obvious that the ideogram in question is in fact that for an amphora? Again, I repeat, the Mycenaean scribes never used any device without a reason. In this particular case, the reason, I believe, is apparent. Any scribe who places the syllabogram $a$ inside the ideogram for what is probably an amphora anyway, does so on purpose to draw our attention to the fact that he is tagging said vessel as a highly valuable and very likely ornate specialty amphora fashioned specifically for the palace elite, and not any old amphora at all, as we see illustrated below: (Fig. 12)

The distinction is crucial. I can conceive of no other reason why any Mycenaean scribe would resort to such a ploy other than to identify the vessel in question as a precious commodity. Similarly, the simplified and streamlined syllabogram $s a$ inside the ideogram for a vessel on a stand is, in my estimation, almost certainly the supersyllabogram for an unknown pre-Greek, possibly Minoan word for raw flax, the agricultural crop the ancient Greeks

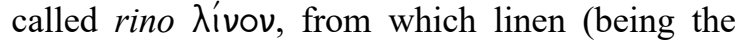
selfsame word in both Mycenaean and ancient alphabetical Greek) is derived. Both of these supersyllabograms are incharged, a term I have had to coin to describe the presence of syllabograms inside ideograms, given its complete absence in previous research on so-called "adjuncts" to Linear B ideograms, in other words, supersyllabograms.

Yet the twinning of supersyllabograms in the vessels sector of the Minoan-Mycenaean economy is even more complex in some instances. For instance, the supersyllabogram no (Linear B Latinized) issuperimposed (supercharged) onto the ideogram for a (soup) bowl. What can this mean? In this position, no is the first syllable of the Mycenaean word noperea $2=$ nopereha $\nu \omega \phi \varepsilon \lambda \lambda_{\varepsilon} \alpha$, meaning "useless", in other words "defective" for inventorial purposes. The syllabogram no is not incharged because it does not represent an innate characteristic of the vessel in question. The bowl just so happens to be broken, hence, "useless". Any supersyllabogram playing this rôle is said to be associative. The factor the supersyllabogram represents is merely associated with the object in question. It does not inherently define it. While associative supersyllabograms are relatively rare in the pottery and vessels sector of the Minoan-Mycenaean economy, they proliferate in the agricultural sector. But that is a topic for another time and place. I shall necessarily address this attendant phenomenon in a future article, which will serve to extrapolate, define and classify all 35 supersyllabograms I have isolated to date in every single sector of the Minoan-Mycenaean economy in a syllabary of 61 syllabograms. The incidence of so many supersyllabograms, accounting for fully 57 $\%$ of all syllabograms, is statistically so prevalent and so significant that we simply cannot afford to ignore it. As it so happens, neither type of dependent supersyllabogram, associative or attributive, 


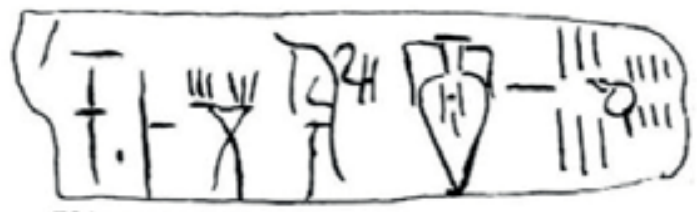

$701 \mathrm{M}$ a 11 (xooxix) (L)

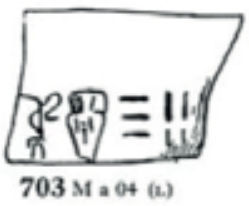

$703 \mathrm{M}$ a $04(\mathrm{~L})$

701 to .danwa. (logogram) meri (ideogram) amphora with syllabogram $\boldsymbol{a}$ incharged ${ }_{130}$ do * 7 (do * - possibly the first syllable of $\hat{\text { dora }} \delta \omega \rho \alpha=7$ gifts (makes sense in this context) danwa. ? 703 (logogram) meri (ideogram) amphora, SSYL a 34 (or more)
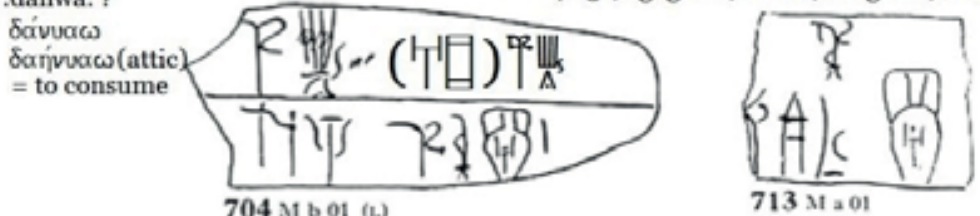

704 (aya)meno... one (logogram) meri (ideogram) amphora, $\boldsymbol{a}$ incharged 1 713 doera (logogram) meri (ideogram) amphora $\boldsymbol{a}$ incharged

Translations:

701 (to.. left truncated?) (to) consume, fresh honey for eventual storage in 30 amphorae, of which 7 are gifts, i.e. to?... 7 amphorae of fresh honey as gifts to be consumed, the rest of it to be stored in amphorae

703 honey to be stored in 34 (or more) anphorae

704 inscribed... one? honey to be sored in 1 amphora

713 a female slave prepares honey to be poured into an amphora -or-

a female slave pours honey into an amphora

NOTE that the notion of the verb -pour- is implicit in the position of the logogram -meri- (top left)

Fig. 13 Mycenaean Linear B tablets from Knossos sporting

the supersyllabogram A for - amphora - and the logogram MERI for - honey -

was ever systematically isolated and tabulated in Mycenaean Linear B until I took it upon myself to do so last year, in 2014. To date, I have discovered, identified \& classified some twenty-five (25) attributive supersyllabograms alone in all sectors (exclusive of associative).

In the case of vessels concerned with the production, manufacture, distribution and consumption of honey, things get downright complex. As we readily ascertain from the ideograms for vessels intended for honey, the supersyllabograms are not only not merely syllabograms, but logograms, in so far as they superimpose the syllabogram $r i$ on top of that for me. The resultant logogram is then surcharged onto each vessel, functioning in one of three possible ways. Once again, we are faced with a non-hypothetical real world question. Why do the scribes surcharge the logogram for honey, sometimes to the left of the vessel, sometimes to the top-left, and sometimes on top? Although we can never really know why, given that we were not there when the scribes deployed this strategy, we owe it to ourselves to try and pinpoint precisely what each of these 3 positions for the logogram meri $=\mu \dot{\varepsilon}^{\prime} \lambda_{\mathrm{I}}$ must have meant to the scribes themselves. I have ventured my own tentative explanations in my translations of 4 tablets concerned with honey from Knossos: (Fig. 13)

I urge readers to consult Carlos Varias García's textual analysis of these and a few other tablets relative to the production of honey at Knossos and Pylos ${ }^{15}$.

\section{CONCLUSIONS}

As it turns out, in a syllabary of 61 syllabograms, at least 35 (at my last count) or fully $57 \%$ are supersyllabograms. That is a staggering return for the scribes' deliberate and eminently practical investment in what is a remarkably clever stock

15 García, Carlos Varias. 1979

The Word for 'honey' and Connected Terms in Mycenaean Greek, MYCAc: 403-418. (illustrated with these and other Knossos tablets surcharged with MERI on pp. 417-418) 
technique to shortcut lengthy text, which would have otherwise simply cluttered up the very small Linear B tablets they routinely worked with (rarely more than $15 \mathrm{~cm}$. Wide). Supersyllabograms are therefore one of the most significant standard key components of the Mycenaean Linear B syllabary, and as such must be fully accounted for as a unique and discrete phenomenon, without which any approach to the interpretation of the Linear B syllabary is at best incomplete, and at worse, severely handicapped. I would even go so far as to claim unequivocally that it is impossible to effectively translate a great many Linear B tablets - and by this I mean well in excess of 800 (22.86 $\%$ ) in an extant repository of some 3,500 intact tablets at Knossos alone. Scribal use of supersyllabograms is, curiously enough, almost exclusively, but not completely, restricted to Knossos. There are a few exceptions, most notably at Pylos.

Why then did the entire collegiate of scribes so often resort to this strategy? Since it was critical for the scribes to consume as little space as possible on what are ostensibly extremely small tablets, the use of supersyllabograms as a substitute for wasteful text is illustrative of just how far the scribes were willing to go to save such invaluable space. They did not do this only occasionally. They did it a great deal of the time, and they always followed the exact same formula in so doing. Thus, any attempt at the decipherment of the in excess of 800 extant Linear B tablets which have at least one and often as many as five supersyllabograms incised on them, some of which have no text whatsoever on them, is bound to result in meaningless gibberish, or in nothing so much as a reductio ad absurdum. No such phenomenon exists on the Linear B tablets. They are all pregnant with meaning. It is up to us as specialists in Mycenaean Linear B to extract that meaning, text or no text.

\section{ABBREVIATIONS}

THE FOLLOWING ABBREVIATIONS ARE ALWAYS USED FOR THE SOURCES THEY REPRESENT:

- AJA American Journal of Archaeology

- ANCL L'Antiquité classique

- CAMB Proceedings of the Cambridge Colloquium on Mycenaean Studies. Palmer, R.L.

- \& Chadwick, John, eds. Cambridge: Cambridge University Press, (C) 1966. First

- paperback edition, (C) 2011. vii, 309 pp. ISBN 978-1-107-40246-1 (pbk.)

- CMLB Duhoux, Yves and Morpurgo Davies, Anna, eds. A Companion to Linear B: Mycenaean Greek Texts and their World. Vol. I. Bibliothèque des Cahiers de l'Institut de Linguistique de Louvain 120). Louvaine-laNeuve, France: Peeters, 2014. 292 pp. ISBN 978-2-7584-0192-6(France)

- ECR Economic History Review

- JHS Journal of Hellenic Studies

- KADM Kadmos: Zeitschrift für Vor- und Frühgriechische Epigraphik

- MIN Minos: Revista de Filología Egea. ISSN: 0544-3733

- MINR Minerva: Revista de Filología Clasíca

- MYCAa Risch, E. \& Mühlestein, H., eds. Colloquium Mycenaeum. Actes du sixième colloque international sur les textes mycéniens et égéens tenu à Chaumont sur Neuchâtel du 7-13 septembre 1975, Neuchâtel. Genève : Librairie Droz. 1979

- MYCAb Olivier J.-P., éd. Mykenaïka: Actes du IXe Colloque international sur les textes mycéniens et égéens, organisé par le Centre de l'Antiquité Grecque et Romaine de la Fondation Hellénique de l'École française d'Athènes (sic) (Athènes, 2-6 octobre 1990). Paris: BCH, Suppl. 25. (C) 1992

- MYCAc Carlier, P., de Lamberterie, C., et al. Études Mycéniennes 2010. Actes du XIIIè colloque international sur les textes égéens, Sèvres, Paris, Nanterre, 20-23 septembre 2010. Pisa et 
Roma, 2012

- PALM Palmer, L. R. The Interpretation of Mycenaean Texts. Oxford: Oxford University Press. 1963. Special Edition for Sandpiper Books Ltd., (C) 1998. xiii, 488 pp.

- PASR Pasiphae: Rivista di filologia e antichità egee

\section{BIBLIOGRAPHY}

Bennett, E. L. 1951

The Pylos Tablets: A Preliminary Transcription. Princeton: Princeton University Press.

Bennett, E. L. 1955

The Pylos Tablets: Texts of the Inscriptions Found, 1939-1954. London: Institute of Classical Studies.

Bennett, E. L. 1955

The Olive Oil Tablets of Pylos. Texts of Inscriptions Found, MIN. Supp. 2.

\section{Bennett, E. L. and Olivier, J-P. 1973}

The Pylos Tablets Transcribed, Incunabula Grae$c a$. Vol L1. Roma: Edizioni Dell'Ateneo. Moulos 63.

Bennett E. L. Jr., Driessen J. M., et al. 1989

436 raccords et quasi-raccords de fragments inédits, MIN 24: 199-242.

\section{Bennett E. L. 1992}

A Selection of Pylos Tablets Texts in, Olivier Jean.Paul, ed. MYCAb. Paris: BCH (Suppl. 25 Chadwick, John, Killen, John T. and Olivier, 110. Jean Paul 1971

The Knossos Tablets. 4th ed. London: Cambridge University Press.

Duev, R. 2007

Zeus and Dionysius in light of the Linear B records, PASR I: 223-230.
Duhoux, Y. 1976

Aspects $d u$ vocabulaire économique mycénien (cadastre - artisanat - fiscalité). Amsterdam: A. M. Hakkert.

Finley, M. I. 1957

The Mycenaean Tablets and Economic History, ECR 10: 128-141.

\section{García, Carlos Varias 2002-2003}

Industria y comercio en la sociedad Micénica, MINR: 11-37.

\section{García, Carlos Varias 2014}

Po-ti-ni-ja si-to-Po-ti-ni-ja en las inscripsciones en Lineal B de Micenas: 189-199 in, Bernabé, Alberto \& Luján, Eugenio R., eds. Donum Mycenologicum: Mycenaean Studies in Honour of Francisco Aura Jorro. Walpole, Ma: Peeters, Louvaine-la-Neuve.

Hiller S. 1987

A-pi-qo-ro amphipoloi, MIN 20-22: 239-255.

\section{Hopkins, K. 2013}

Mycenaeans at Late Minoan IIIC Halasmenos, East Crete, Aesthesis, Undergraduate Journal of Classical Studies (Stanford University) II, spring 2013: 43-53.

Hruby, J. 2010

Mycenaean Pottery from Pylos: an Indigenous Typology, AJA 114, no. 2: 195-216.

Judson, A. P. 2013

The Linear B Stirrup Jars, KADM 52, no. 1: 69-

\section{Killen J. T. 1985}

The Linear B Tablets and Mycenaean Economy, in Morpurgo, Davies A. \& Duhoux Y., eds. Linear B: A 1984 Survey: Proceedings of the Mycenaean Colloquium of the VIIIth Congress of the International Federation of the Societies of Classical 
Studies (Dublin, 27 August -1st September 1984).

Louvain-La-Neuve: Peeters.

\section{Killen J. T. 2014}

Mycenaean economy, CMLB. Vol. I.

\section{Killen J. T. and Olivier, J.-P. 1965}

The Knossos Tablets. A Transliteration, ANCL 34, no 1: 292-294.

Killen J. T. and Olivier, J.-P. 1966

Le récapitulatif du cadastre Ep de Pylos. CAMB.

Mavridis, Dimitrios, G. 1972

On the Knossos Mc Tablets, MIN 13, 1972: 29-54.

\section{Mavridis, Dimitrios, G. 1994}

133 Joins and Quasi-Joins of Fragments in the Linear B Tablets from Pylos, MIN 27-28, 19921993: 271-289.

\section{Melena, José L. 1995}

28 Joins and quasi-joins of Fragments in the Linear B Tablets from Pylos, MIN 29-30, 1994-1995: 95-100.

Melena, José L. 1977

On the New Linear B Inscription from Mycenae, MIN 16: 17-18.

\section{Olivier, J.-P. 1999}

El comercio micénico desde la documentación epigráfica, MIN 31-32: 275-292

\section{Palmer, L. R. 1963 (PALM)}

The Interpretation of Mycenaean Texts. Oxford: Oxford University Press. Special Edition for Sandpiper Books Ltd.

\section{Ruigh, C. J. 1981}

Interpretation hypothetique de la tablette $\mathrm{Va} 15 \mathrm{de}$ Pylos, ŽivaAnt 31: 47-62.

\section{Ruigh, C. J. 1987}

La tavoletta di Pilo Tn 316: una registrazione di carattere eccezionale?, MIN 20-22: 551-555.

\section{Stockhammer, Philipp W. 2011}

An Aegean Glance at Megiddo: 282-296 in, Our Cups Are Full: Pottery and Society in the Aegean Bronze Age Papers presented to Jeremy B. Rutter on the occasion of his 65th birthday Edited by Walter Gauß, et al. Oxford: Hadrian Books (Archaeopress, Publishers of British Archaeological Reports).

\section{Ventris, M. and Chadwick, J. 1973}

Documents in Mycenaean Greek. Cambridge: Cambridge University Press. (2nd. Edition) 2 Vols.

\section{Weilhartner, J. 2012}

Religious offerings in the Linear B Tablets: an attempt at their classification and some thoughts about their possible purpose, Faventia, Supplementa 1. Núm. Extra, 2012: 207-231.

\section{ELECTRONIC PERIODICALS (PDF):}

\section{Driessen, J. et al.}

Two more Linear B inscribed stirrup jars from Malia: 25-40 (academia.edu). https://www.academia.edu/5221541/Two_more_Linear_B_inscribed_stirrup_jars_from_Malia

\section{Hutton, W. F.}

The Meaning of QE-TE-O in Linear B: 105-131. PZN INT CANADA (University of Calgary, Department of Classics). nd. (undated). PDF (bibliographic information lacking). To retrieve, search Google under the title \& click to open the PDF.

\section{Kelly, A. 2006}

Homer and History: Iliad 9.381-4. (with frequent references to Mycenaean Linear B): 321-333. (ac- 
ademia.edu) https://www.academia.edu/2351263/

Homer_and_History_Iliad_9.381_4

\section{Macdonald, C.}

Rejection and revival of traditions: Middle Minoan II-IIIA footed goblets or eggcups at Knossos. [7] Driessen[7]: 203-211 (academia.edu) https://www.academia.edu/883499/_Rejection and_revival_of_traditions_Middle_Minoan_II_ IIIA_footed_goblets_or_eggcups_at_Knossos in_O._Krzyszkowska_ed._Cretan_Offerings. Studies_in_Honour_of_Peter_Warren._London British_School_at_Athens

\section{Martinotti, Enriqueta et Tina 2007}

Nouvelle interprétation des tablettes mycéiennes. Traduction du Linéaire $B$ dans les tablettes $39=A S$ 1517 (LXXXVIII), de Cnosos et $31=$ AE 04 [134], 2007. $<$ hal-00193886v3>: 1-53

\section{Martinotti, Enriqueta et Tina 2008}

Linéaire $B$ : le préjugé comptable et pictographique d'un syllabaire logographique, phonologique et polysémantique. (sans pagination, unpaginated). hal-00311652, version 3-10 sep 2008.

\section{Martinotti et Tina}

Linéaire B: TI-RI-PO-DE et l'iconogramme "tripode" dans la tablette 236=Ta 641 de Pylos: 1-8, in HAL Id: hal-00231077

https://hal.archives-ouvertes.fr/hal-00231077v4

$21 \mathrm{Jul}$ 2014. HAL is a multi-disciplinary open access archive for the deposit and dissemination of scientific research documents, whether they are published or not.

Vallance J. R. 2015

The Gezer Agricultural Calendar Almanac in Paleo-Hebrew (ca. 925 BCE) and its Translation into Mycenaean Linear B, Coupled with the Profound Implications of the Powerful Impact of Supersyllabograms aka Surcharged Adjuncts on Linear B (academia.edu) https://www.academia. edu/12678574/The_Paleo-Hebrew_Gezer_Agri-
cultural_Calendar_or_Almanac_translated_into_ Mycenaean_Linear_B

\section{Van Alfen, P.}

The Linear B Inscribed Stirrup Jars: 235-242 \& 251-274 (academia.edu)

https://numismatics.academia.edu/PeterVanAlfen

\section{Ventris $\mathbf{M}$.}

The Ventris Papers. Institute of Classical Studies (Series: Collections and Projects: ICS Michael Ventris Archive). London: University of London, School of Advanced Study. Duplicate copy at Austin: University of Texas. 36.

http://www.icls.sas.ac.uk/research/archives\#Ventris Papers 


\section{REZIME}

\section{ARHEOLOŠKI PREVOD TABLE SA PILOSA TA 641-1952 (VENTRIS), SA PRIKAZOM SUPERSILABO- GRAMA U MIKENSKOM LINEAR B PISMU}

U saradnji s Asocijacijom za istorijske studije, Koryvantes (Atina), organizacija, Linear B Knosos i Mikena (Wordpress), sprovodi kontinuirano istraživanje mikenske arheologije i u sklopu toga mikenskog grčkog dijalekta. U ovoj studiji centar pažnje smo usmerili na nedavno dešifrovanu tablu sa pilosa TA 641-1952 (Ventris). Istraživač Rita Roberts sa Krita je po svemu sudeći svojim dešifrovanjem ostvarila najprecizniji prevod ovog zapisa do sada. Uveden je novi termin u Mikenskom Linearu B, supersilabogram, što predstavlja prvi silabogram ili prvi slog bilo koje reči ili fraze u Linearu B. Supersilabogrami su pogrešno nazivani "dodaci” u ranijim lingvističkim istraživanjima Mikenskog pisma Linear B. U ovom prilogu smo pokušali da doprinesemo boljem razumevanju Linear B pisma, pokazujući da funkcionalnost supersilabograma znatno prevazilazi ranija ograninečenja i da supersilabogram predstavlja jedinstven fenomen bez kojeg bi bilo kakav pokušaj tumačenja linear B pisma bio nepotpun ili još gore pogrešan. 